1 Destabilization of $\beta$-cell FIT2 by saturated fatty acids contribute to ER stress and

2 diabetes.

3

4 Xiaofeng Zheng ${ }^{1,2,3}$, Qing Wei Calvin $\mathrm{Ho}^{1}$, Minni Chua1 , Olga Stelmashenko ${ }^{1,2}$,

5 Sneha Muralidharan ${ }^{4}$, Federico Torta ${ }^{5}$, Elaine Guo Yan Chew ${ }^{1,6}$, Michelle Mulan

6 Lian $^{1,6}$, Jia Nee Foo ${ }^{1,6}$, Markus Wenk ${ }^{5}$, David L. Silver ${ }^{7}$, Per-Olof Berggren ${ }^{1,2,3,8,9}$,

7 Yusuf Ali ${ }^{1,2,9,10}$

8

$9{ }^{1}$ Lee Kong Chian School of Medicine, Nanyang Technological University Singapore, 10 Singapore 308232.

112 Singapore Eye Research Institute (SERI), Singapore General Hospital, Singapore 168751.

$13{ }^{3}$ Center for Diabetes and Metabolism Research, Department of Endocrinology and

14 Metabolism, West China Hospital, Sichuan University, Chengdu 610041, Sichuan

15 Province, P.R.C.

$16{ }^{4}$ Singapore Lipidomics Incubator, Department of Medicine, National University of

17 Singapore.

$18{ }^{5}$ Singapore Lipidomics Incubator, Department of Biochemistry, Life Sciences

19 Institute and Yong Loo Lin School of Medicine, National University of Singapore.

$20{ }^{6}$ Human Genetics, Genome Institute of Singapore, A*STAR, Singapore 138672,

21 Singapore.

$22{ }^{7}$ Signature Research Program in Cardiovascular and Metabolic Disorders, Duke-

23 National University of Singapore Graduate Medical School, Singapore 169857.

$24{ }^{8}$ The Rolf Luft Research Center for Diabetes and Endocrinology, Karolinska

25 Institutet, Karolinska University Hospital L1, SE-171 76 Stockholm, Sweden. 
bioRxiv preprint doi: https://doi.org/10.1101/2021.02.28.433270; this version posted February 28, 2021. The copyright holder for this preprint (which was not certified by peer review) is the author/funder, who has granted bioRxiv a license to display the preprint in perpetuity. It is made available under aCC-BY 4.0 International license.

\section{$26{ }^{9}$ Senior authors}

2710 Address correspondence to Associate Professor Yusuf Ali, yusuf.ali@ntu.edu.sg,

28 https://orcid.org/0000-0002-0681-1125 


\section{ABSTRACT}

32 Western type diets are linked to obesity and diabetes partly because of their high saturated fatty acid (SFA) content. We found that SFAs, but not unsaturated fatty acids

34 (USFAs), reduced the number of lipid droplets (LDs) within pancreatic $\beta$-cells. 35 Mechanistically, SFAs but not USFAs disabled LD biogenesis by inducing palmitoylation and subsequent ERAD-C mediated degradation of LD formation protein,

37 Fat storage-Inducing Transmembrane protein 2 (FIT2). Targeted ablation of FIT2 reduced $\beta$-cell LD numbers, lowered $\beta$-cell ATP levels, reduced Ca2+ signaling, downregulated $\beta$-cell transcription factors (RNA sequencing analysis), and exacerbated diet-induced diabetes in mice. Subsequent mass spectrometry studies revealed increased C16:0 ceramide accumulation in islets of mice lacking $\beta$-cell FIT2 under lipotoxic conditions. Inhibition of ceramide synthases ameliorated the enhanced ER stress. Overexpression of FIT2 increased number of intracellular LDs and rescued

44 SFA-induced ER-stress and apoptosis thereby highlighting the protective role of FIT2 and LDs against $\beta$-cell lipotoxicity and diet-induced diabetes.

\section{KEYWORDS}

Palmitate, FIT2, lipid droplets, ER stress, pancreatic $\beta$-cells, diet-induced diabetes 


\section{INTRODUCTION}

Numerous evidences show that saturated fatty acids (SFAs) trigger ER stress, cell

dysfunction and apoptosis in a myriad of cell types $(1,2)$. In contrast, unsaturated fatty acids (USFAs) remain relatively benign with some reporting opposite effects to SFAs $(3,4)$. The mechanism underlying this difference remains unclear. This is especially true for a cell-type as important as the pancreatic $\beta$-cell, where its vulnerability to fatty acid (FA) (i.e. lipotoxicity) reduces insulin provision and leads to diabetes (5). $\beta$-cells, as with all eukaryotic cells, possess the ability to generate intracellular lipid-containing organelles known as lipid droplets (LDs)(6).

63

LDs are highly conserved cytosolic organelles that originate from ER. They contain a hydrophobic core of de novo assembled neutral lipids and cholesterol esters, surrounded by a monolayer of phospholipids and cholesterol (7-9). An accumulating body of evidence suggests that the biological roles of LDs are broader than initially anticipated. Beyond mere lipid storage containers, LDs were shown to act as hubs for innate immune defence, modulators of nuclear function and sites for protein storage and trafficking (10-12). The number of LDs present in a cell can dictate its energy rate,

71 inflammation state, resistance to pathogens, ER stress, and cell death. LD biogenesis

72 is a complex process involving many different ER resident enzymes, including those

73 that are involved in the synthesis of neutral lipids and cholesterol esters such as

74 DGATs (13). However, LD formation is largely dependent on a highly conserved 75 tripartite ER protein machinery comprising of seipins, perilipins, and FITs (14, 15). A modification in each of these proteins affect LD biogenesis from the ER (13). 
78 Despite considerable attention and the link to many diseases, the contribution of LDs

79 to $\beta$-cell dysfunction and diabetes is just beginning to emerge. LDs are present in $\beta$ cells and notable differences in LD numbers were observed between rodent and

81 human $\beta$-cells, with the latter increasing in numbers per $\beta$-cell with age (16). Our

82 underpinning observation of a significant change in LD number between murine $\beta$ -

83 cells exposed to SFAs with those exposed to USFAs, prompted a detailed mechanistic study on how SFAs may directly influence LD numbers in $\beta$-cells, and in turn how this regulation impacts $\beta$-cell function and whole-body glucose homeostasis. In this process, we uncovered a mechanism by which SFAs reduce LD numbers in $\beta$-cells with impact on $\beta$-cell function and survival, as well as overall glucose homeostasis.

Among the different proteins important for LD formation, we found that only the Fat storage-Inducing Transmembrane protein 2 (FIT2/FITM2), was rapidly downregulated with physiological levels of SFAs, but not with USFAs. FIT2 belongs to a unique family 92 of evolutionarily conserved ER-resident, 6-transmembrane domain, protein with its only other member being FIT1/FITM1 $(17,18)$. FIT1 is primarily expressed in skeletal muscle, with lower levels found in heart, while FIT2 is ubiquitously expressed in tissues albeit at different levels (17). The highest levels of FIT2 were reported to be in both white and brown adipose tissue and the critical role of FIT2 for LD formation was 97 shown in skeletal muscle, adipose tissue, and the small intestine (17, 19-21). FIT2, a 98 critical protein for LD formation, has been shown to promote ER lipid coalescence and LD formation, a function that is likely linked to its catalytic lipid phosphatase activity $(15,18,22,23)$. Most recently, FIT2 was implicated in ER protein dysregulation, ER 101 structure maintenance and the maladaptive ER response in both yeast and 
102 mammalian cells $(23,24)$. Despite this, the role and importance of FIT2 in $\beta$-cell LD

103 formation, function and survival, especially during lipotoxicity, remain unknown.

104

105 Herein, we confirmed FIT2 presence in $\beta$-cells of mouse islets and we showed that

106 SFA affects FIT2 levels post-translationally through palmitoylation, increased

107 MARCH6 (E3 ligase) association, and proteasomal degradation in mouse insulinoma

108 MIN6 cells. This loss, mimicked in a $\beta$ FIT2KO mice ( $\beta$-cell specific deletion of FIT2),

109 resulted in reduced $\beta$-cell LD numbers and diet-induced diabetes with exacerbated

110 glucose intolerance due to a reduced insulin secretory response. We found ceramide

111 accumulation, a key driver of $\beta$-cell ER stress, in islets of $\beta$ FIT2KO mice. Rescue of

112 FIT2 in MIN6 cells, through overexpression, partially restored LD biogenesis, reduced

113 ER stress and ameliorated SFA-mediated $\beta$-cell apoptosis (i.e., lipotoxicity). Beyond

114 the conceptual advance of diet affecting $\beta$-cell function, this study highlights

115 restoration of the $\beta$-cell LD formation as a potential way to preserve its function, 116 especially in states of obesity. 


\section{RESULTS}

\section{Palmitate prevents $\beta$-cell lipid droplet accumulation through FIT2.}

121 To recapitulate $\beta$-cell vulnerability to SFAs, we first exposed MIN6 cells to 122 physiologically relevant levels of either oleate $(300 \mu \mathrm{M})$ or palmitate $(300 \mu \mathrm{M})$.

123 Exposure to oleate led to increased lipid droplets whereas exposure to palmitate did not (Fig 1A, B). We next determined the relative abundance of proteins critical for LD protein was downregulated by palmitate (16:0) and stearate (18:0), with levels lower

127 compared to that of BSA-treated control cells. However, FIT2 was not downregulated 128 by the chain-length equivalent USFA, palmitoleate (16:1) and oleate (18:1), respectively (Fig 1C, Supplementary Fig 1A - D). The loss of FIT2 corresponded with an increase in C/EBP Homologous Protein (CHOP) protein levels, a major downstream pro-apoptotic arm of the maladaptive endoplasmic reticulum (ER) stress

132 response. In addition to MIN6 cells, FIT2 protein was also observed to be 3-fold lower

133 in pancreatic islets from hyperphagic, obese, and diabetic, $\mathrm{db} / \mathrm{db}$ mice compared to 134 their non-diabetic littermates (where FIT2 mRNA co-localized with insulin-positive 135 pancreatic $\beta$-cells) (Fig 1D, E, Supplementary Fig 1E). The reduced FIT2 protein abundance in $\mathrm{db} / \mathrm{db}$ islets corroborates with prior evidence of reduced LD number in

$137 \beta$-cells from diabetic mice (16). To confirm the role of FIT2 in reduced $\beta$-cell LD, we 138 generated MIN6 cells lacking FIT2 (Fit2 shRNA, with 90\% knockdown efficiency) 139 (Supplementary Fig 1F). In parallel, mice bearing floxed (FL) Fit2 alleles were bred 140 with knockin mice bearing Cre recombinase inserted into the Ins2 locus (RIP-Cre), to 141 achieve $\beta$-cell deletion of FIT2 ( $\beta$ FIT2KO) (Supplementary Fig 1G, H). Concern of RIP142 Cre "leakiness" in certain regions of the brain, specifically the hypothalamus (25), was 
143 addressed by showing no change in Fit2 mRNA expression in extra-pancreatic tissues

144 (Supplementary Fig 2A), and by reporting no observable changes in IPGTT, except

145 for a modest but significant increase in glucose excursion in RIP-Cre mice compared

146 to wild-type mice, a well-documented RIP-Cre observation (26). There were no

147 changes in ITT between the different mouse lines used (i.e. wild-type, RIP-Cre, floxed-

148 Fit2 and BFIT2KO) (Supplementary Fig 2B - F). FIT2 downregulation significantly

149 reduced LD number both in MIN6 cells (Fig 1F, G) and in $\beta F I T 2 K O$ mouse islets, and

150 the difference was exacerbated when $\beta F I T 2 K O$ mice were placed on a moderate-SFA

151 Western diet (West; a diet where saturated fat accounts for $40 \%$ of total energy) for

15225 weeks (Fig 1H, I). Taken together, these results suggest LD accumulation,

153 previously observed in human $\beta$-cells (16), as an added feature that distinguishes a $\beta$ -

154 cell response to either oleate or palmitate. The failure to accumulate LDs following 155 palmitate exposure correlates with a loss of FIT2 protein in $\beta$-cells.

157 Loss of $\beta$-cell FIT2 exacerbates diet-induced diabetes.

158 Since $\beta$-cell FIT2 levels were observed to be linked to FA exposure, we determined 159 whether its loss impacted whole body glucose homeostasis. Loss of FIT2 in $\beta$-cells resulted in a modest but significant increase in plasma glucose concentration following 161 bolus intra-peritoneal injection of glucose in chow-fed $\beta F I T 2 K O$ mice (Fig 2A, B). 162 However, the increased plasma glucose concentration observed in $\beta F I T 2 K O$ mice was 163 exacerbated in West diet fed (25 weeks) mice (Fig 2A, B). These results suggest that $164 \quad$ BFIT2KO mice were metabolically worse off when placed on a West diet as compared to West-fed floxed-control mice. Subsequent analysis showed that the poor glycemic control in $\beta F I T 2 K O$ mice was driven by a significantly muted insulin response to high 167 glucose, both in vivo and ex vivo, and not by changes in peripheral insulin sensitivity 
168 (Fig 2C $-2 \mathrm{G}$ ). There were no discernible differences in islet morphology, islet cell composition, $\beta$-cell size, islet insulin content and insulin granule morphology between $\beta$ FIT2KO and floxed control mice (Supplementary Fig 3A - F). Rather, the muted

171 insulin response in $\beta F I T 2 K O$ islets could be linked to an observed reduction in cellular

172 ATP and a blunted glucose-stimulated intracellular $\mathrm{Ca}^{2+}$ influx (Supplementary Fig $3 \mathrm{G}$

$173-\mathrm{I}$ ). A subsequent comparative RNA-seq analysis between islet cells from $\beta F I T 2 K O$ and floxed control mice revealed distinct gene expression changes in (i) vesicle fusion and exocytosis, (ii) ATP binding, (iii) $\mathrm{Ca}^{2+}$ transport and, (iv) ER-related genes as well as a significant downregulation of genes (such as $\mathrm{Pdx1}$, MafA, Nkx6.1, Pax6) required

177 for $\beta$-cell function (Fig $2 \mathrm{H}, \mathrm{I}$ ). These results lend support to earlier phenotypic 178 observations of poor glucose control due to reduced $\beta$-cell function in $\beta F I T 2 K O$ mice.

\section{Loss of FIT2 increases $\beta$-cell ceramides and exacerbates ER stress.}

181 The inability of $\beta$-FIT2KO mice to cope with a chronic 25 -week exposure to West diet

182 was further scrutinized. We observed higher levels of $p-I R E 1 \alpha^{+} /$insulin $^{+}$cells and

$183 \mathrm{ATF}^{+} /$insulin $^{+}$cells in West-fed $\beta-F I T 2 K O$ (KO West) mice compared to the West-fed

184 floxed control (FL West) mice (Fig 3A - D). This suggests that loss of FIT2 in $\beta$-cells

185 increased the maladaptive ER stress response in vivo. Exposure to FA (especially palmitate) triggers an ER stress response, an important driver of $\beta$-cell dysfunction (27,

187 28). Therefore, we determined whether $\beta$-cell FIT2 and LDs played any part in the 188 palmitate-induced ER stress response. In FIT2 knockdown MIN6 cells (FIT2 shRNA), 189 p-IRE1 $\alpha$ was found to be significantly elevated, with a time-dependent increase in IRE190 1, ATF4 and CHOP protein levels compared to control MIN6 cells (Fig 3E; 191 Supplementary Fig 4A - D). The amplified ER stress response (ATF4, CHOP and IRE1921 pathways) coincided with increased cell death (Fig 3F, G), and a significantly 
193 elevated activity of caspase-3/7, suggesting increased apoptosis in palmitate-treated

194 FIT2 shRNA cells compared to palmitate-treated control cells (Fig 3H). Liquid chromatography-mass spectrometry (LC-MS) analysis of ceramide levels in pancreatic islets isolated from KO West and FL West (fed) mice revealed accumulation

197 of toxic C16 ceramide (Cer d18:1/16:0), in the $\beta$-FIT2KO islets (Fig 3I). Similarly, there 198 was a modest increase in the ceramide precursor C16 dihydroceramide (Cer $\mathrm{d} 18: 0 / 16: 0)(p=0.055)$ and in other dihydroceramides containing saturated fatty acyl chains, suggesting enhanced de novo ceramide synthesis in islets lacking FIT2. A toxic accumulation of ceramides in $\beta$-cells was corroborated by immunofluorescence (IF) analysis in $\beta$-FIT2KO mice (Supplementary Fig 4E and F) and co-treatment of palmitate with Fumonisin B1 (FB1), a pharmacological inhibitor of ceramide synthases, reduced CHOP levels (Fig 3J, K) (29). Together, these data suggest that ceramide accumulation contributed to enhanced ER stress and dysfunction in West-fed $\beta$ FIT2KO mice.

Partial restoration of FIT2 rescues LD biogenesis and mitigates palmitatemediated effects in MIN6 cells.

210 The role of FIT2 loss in SFA-induced $\beta$-cell apoptosis was further investigated through 211 its overexpression in MIN6 cells. MIN6 cells were transiently transfected with either an 212 expression vector encoding FIT2 (pcDNA3.1-FIT2) or with a control vector (pcDNA3.1213 mock) prior to palmitate (or BSA) exposure. FIT2 levels increased by approximately 3214 fold in FIT2-overexpressing (FIT2-OE) cells treated with BSA, compared to control 215 (mock cells) (Fig 4A, B). While palmitate exposure resulted in an approximately 95\% 216 reduction of FIT2 in mock cells, this was partially attenuated in FIT-OE cells 217 (approximately 55\% reduction) (Fig 4A, B). This suggests that overexpression of FIT2 
218 partially compensated for palmitate-induced reduction in FIT2 protein levels. This

219 partial restoration of FIT2 in FIT-OE cells exposed to palmitate led to a modest but

220 significant increase in the number of LDs (Fig 4C, D), suggesting a partial rescue of

221 palmitate-induced LD loss in $\beta$-cells. This rescue followed with a corresponding

222 reduction in CHOP protein levels and lowered caspase-3/7 activity in FIT2-OE cells

223 exposed to palmitate (Fig 4E, F). Together, these results suggest that partial

compensation of FIT2 loss ameliorates palmitate-induced lipotoxicity in $\beta$-cells.

225

Palmitoylation and ERAD-C degradation pathways contribute to FIT2 protein

227 loss.

228 We next sought to elucidate the mechanism that may account for SFA-induced FIT2 229 loss. The observed SFA-mediated downregulation of FIT2 in MIN6 cells was not seen 230 at the transcriptional level (Supplementary Fig 5A) but was abrogated in the presence 231 of proteasome inhibitor MG132 (Fig 5A, B), suggesting that SFAs modulate FIT2 232 protein stability rather than its gene expression in $\beta$-cells. Given that FIT2 is an ER233 resident protein, we then probed the possible involvement of an ER-associated 234 degradation (ERAD) pathway in palmitate-mediated degradation of FIT2. ERAD 235 inhibitor Eeyarestatin I (ES) (30), partially attenuated palmitate induced FIT2 loss (Fig $2365 \mathrm{C}, \mathrm{D})$. Increased association between FIT2 and MARCH6, a mammalian E3 ligase 237 complex responsible for degradation of the ERAD-cytosolic (ERAD-C) substrates (31), 238 was observed in MIN6 cells treated with palmitate (Fig 5E). Furthermore, MARCH6 239 silencing (Supplementary Fig 5B) modestly but significantly rescued palmitate 240 mediated FIT2 loss (Fig 5F, G) and taken together, these results implicate ERAD-C 241 pathway and MARCH6 are involved in palmitate-mediated degradation of FIT2. The 242 ERAD-C pathway is usually triggered by a change in the tertiary conformation of an 
243 ER-protein. We tested the possibility of palmitate directly modifying FIT2 given that an

244 in silico analysis (GPS-lipid) (32) showed high probability of fatty-acid S-acylation

245 taking place at 4 different cysteine residues (Cys-7, Cys-251, Cys-140 and Cys-70)

246 (Supplementary Fig 5C). Indeed, the presence of S-acylation (palmitoylation) on FIT2

247 protein was confirmed with the S-palmitoylation assay, with higher levels of S-acylated

248 FIT2 proteins detected in MIN6 cells exposed to palmitate (Fig 5H). Mutation of all 4

249 predicted S-acylation sites (Cys to Ala) abrogated palmitoylation under steady-state

250 (BSA) and heightened (palmitate) conditions (Fig 5H). Next, to determine whether

251 FIT2 palmitoylation led to its degradation, the palmitoylation inhibitor Cerulenin (33),

252 was added to MIN6 cells together with palmitate. Cerulenin significantly restored

253 palmitate-mediated FIT2 protein loss (Fig 5I, J). Given selectivity concerns of the

254 palmitoylation inhibitor cerulenin, we further determined the stability of the FIT2 mutant

$255(C 7 / 251 / 140 / 70 A)$ in the presence and absence of palmitate (Supplementary Figure

$2565 \mathrm{C}$ ). Single mutation of either cysteine residue modestly, but insignificantly, abrogated

257 palmitate induced FIT2 protein loss (Supplementary Fig 5D, E). However, mutation of

258 all four cysteine residues completely blocked palmitate (Fig $5 \mathrm{~K}, \mathrm{~L}$ ) as well as stearate

259 (Supplementary Fig 5F, G) mediated FIT2 degradation. Altogether, these results suggest that SFA-mediated S-acylation (palmitoylation) of the FIT2 protein promotes

261 its degradation, in an ERAD-C and MARCH6 dependent manner. The loss of FIT2, in 262 turn, triggers the maladaptive ER stress response and apoptosis in $\beta$-cells 263 corroborating a previous finding in eukaryotic cells (23). This pathway that links SFAmediated $\beta$-cell lipotoxicity with FIT2 degradation and reduced LD numbers has not been described previously. 


\section{DISCUSSION}

269 In the present study, we provide the first evidence of a FA-type specific modulation of

270 ER resident, LD formation protein, FIT2 in $\beta$-cells. Our results show that LD biogenesis

271 is affected by the type of FA exposure and that one pathway responsible for differential

272 toxicity between dietary SFA and USFA (in the form of palmitate and oleate, 273 respectively) involves cellular FIT2 protein stability, and the consequent ability of $\beta$ -

274 cells to accumulate LDs. We present a mechanism how SFAs reduce FIT2 levels 275 leading to increased $\beta$-cell ER stress response, reduced insulin secretion and elevated $276 \beta$-cell apoptosis, as well as increased susceptibility to diet-induced diabetes. 277 Altogether, we highlight the underlying novel finding that the ability of $\beta$-cells to 278 withstand lipotoxicity is contingent on its capacity to maintain FIT2 and to generate 279 intracellular LDs.

281 LDs are an important source for organelle membrane lipids and proteins (34). 282 Mitochondrial lipid uptake from ER is essential for maintaining mitochondrial membrane integrity which may be affected by the loss of FIT2 as seen with decreased [ATP]/ [ADP] ratios (in $\beta F I T 2 K O$ islet cells) (35). We observed significant elevation of ER stress-related proteins such as p-IRE1 $\alpha$ and ATF4 in FIT2KD cells and islets of $\beta F I T 2 K O$ mice. Corroborating transcriptomic evidence of ER protein and REDOX gene upregulation in $\beta F I T 2 K O$ islets suggest that loss of LDs induces the maladaptive 288 ER stress response in $\beta$-cells. Accumulation of $C 16: 0$ ceramides in islets of $\beta$-FIT2KO mice can be a strong contributor to the observed ER stress and $\beta$-cell dysfunction. A 290 GENEVESTIGATOR® search revealed CerS5 and CerS6 to be the most abundant 291 ceramide synthases in pancreatic islets (36). CerS5 and CerS6 generate C16 and C14 
292 chain length ceramides, and are likely responsible for the observed difference in C16:0

293 ceramide levels in West-fed $\beta$-FIT2KO islets and West-fed floxed islets $(37,38)$.

294 Further inhibition of ceramide synthesis by Fumonisin B1 ameliorated palmitate295 mediated ER stress in MIN6 cells. When coupled with increased C16:0 ceramides

296 levels in islets that lack FIT2, the data suggests that increased ceramides link $\beta$-cell

297 FIT2 loss with enhanced ER stress, adding to current knowledge of FIT2 loss leading

298 to ER lipid imbalance and ER dysregulation $(23,24)$. We present a pathway for how

299 palmitate drives ER stress, with FIT2 stability and LD accumulation taking the center

300 stage in $\beta$-cells. The data presented here go beyond the past correlates of ceramide

301 synthase inhibition improving GSIS in palmitate-treated $\beta$-cells and reducing apoptosis

302 in TAG-treated macrophages $(29,39)$. Failure to sequester lipids away from the ER

303 increases substrates for ER-localized enzymes serine palmitoyltransferase and

ceramide synthase to enhance ER ceramide levels $(40,41)$. Ceramide accumulation

has been suggested to change the biophysical properties of ER membrane rafts,

306 induce defective ER protein export, disrupt ER $\mathrm{Ca}^{2+}$ homeostasis and subsequently

307 trigger ER stress-mediated apoptosis $(42,43)$. The strongest evidence of lipid-induced

308 ER stress because of FIT2 loss is the observed increased presence of CHOP, a known

309 pre-apoptotic death signal. Thus, under lipotoxic conditions, FIT2 and LDs function

310 critically to sequester and store FAs in their less toxic esterified forms thereby

311 preventing ceramides, especially C16:0, from accumulating within the ER.

313 In a contrasting situation where LDs were allowed to accumulate in $\beta$-cells through

314 desnutrin (a TAG hydrolase) ablation, a similar blunted GSIS response was observed

315 (44). These results seem contradictory to what is reported here as they suggest that

316 the converse, intracellular LD accumulation, is detrimental to $\beta$-cells. However, it is 
317 noteworthy that the significant driver for the reduced GSIS in the desnutrin knockout

318 mice is reduced fatty acid utilization by mitochondria, rather than enhanced $\beta$-cell ER

319 stress. The latter mechanism that supports our findings. To reconcile this perceived

320 difference, it is important to note that while LD formation and lipid sequestration away

321 from the ER mitigates lipotoxicity, this is perhaps on the premise that LD utilization

322 and TAG hydrolysis remains unaffected. Here, further work is required to delineate the

323 dynamics of LD accumulation and LD turnover, especially since higher number of LDs

324 has been observed in human diabetic $\beta$-cells (16). Nevertheless, it is increasingly clear

325 that the formation of LDs, especially during lipotoxic conditions, is critical for preventing

326 ER lipid accumulation and ER stress.

328 A fundamental mechanism governing LD loss is the post-translational modification of

FIT2 by palmitate (and stearate) and its subsequent degradation in $\beta$-cells. This may explain the lack of FIT2 being mentioned in any GWAS or islet RNA-seq related 331 studies, although a recent diabetes meta-analysis study identified an East Asian 332 diabetes-associated loci (RS6017317) in the regulatory region of FIT2 (45). The molecular switch of this protein, and a potential therapeutic strategy, likely involves

334 protein stability maintenance at the ER, as evidenced by a partial rescue of lipotoxicity 335 through FIT2 overexpression alone. Palmitoylation commonly occurs on 336 transmembrane proteins, affecting protein stability and subcellular localization $(46,47)$. 337 Interfering with palmitoylation either pharmacologically or through site-directed 338 mutagenesis reduced palmitate-induced FIT2 degradation, and a similar mechanism 339 was reported in other transmembrane proteins such as TBC1D3 and CDCP1 $(48,49)$. 340 We further identified ERAD-C as the most likely pathway responsible for FIT2 341 degradation with increased MARCH6 and FIT2 protein association in the presence of 
342 palmitate and reduced FIT2 degradation with MARCH6 knockdown. Mutating

343 predicted S-acylated cysteine residues abrogated FIT2 palmitoylation and degradation.

344 Further molecular work correlating degree of FIT2 palmitoylation with its degradation

345 in both physiology and pathology may help improve our understanding on how FIT2

346 function is fine-tuned at the protein level.

348 In conclusion, our results show how physiological levels of dietary SFAs, but not

349 USFAs, disable LD biogenesis in $\beta$-cells. Palmitoylation of FIT2 leads to its 350 degradation likely through ERAD-C mediated mechanisms, with increased association

351 between FIT2 and MARCH6. Loss of FIT2 leads to a significant reduction in $\beta$-cell LDs

352 and increases ceramide accumulation. As a consequence, ER stress hampers $\beta$-cell

353 function and increases $\beta$-cell apoptosis (i.e. lipotoxicity). Beyond FIT2 and the 354 understanding of how SFAs are more damaging than UFAs to cells, our results show 355 that restoration of LD formation, especially in a lipotoxic milieu such as obesity and 356 diabetes, is of considerable therapeutic value for preventing $\beta$-cell dysfunction and 357 loss. 
MATERIALS \& METHODS

Mice

$362 \beta$-cell specific FIT2 knockout mice $(\beta-F I T 2 K O, K O)$ were generated using the Cre-lox 363 recombination system. Mice with floxed FIT2 (FIT2fl/fl, FL) (21) were bred with mice 364 expressing Cre-recombinase, under control of the rat insulin promoter (B6.Cg$365 \mathrm{Tg}(\mathrm{Ins} 2-\mathrm{cre}) 25 \mathrm{Mgn} / \mathrm{J})$. Male mice were used in all animal experiments. $\beta$-FIT2KO and their corresponding floxed littermates (FIT2fl/fl) were fed with western-type (West) diet (D12079B, Research Diets) from 5 weeks of age for a further 25 weeks. B6.BKS (D)$\operatorname{Lepr}^{\mathrm{db}} / \mathrm{J}(\mathrm{db} / \mathrm{db})$ mice were compared with their age-matched heterozygous littermates $369(\mathrm{db} /+)$ at 16 weeks. Mice were housed in a facility with a 12-h light-dark cycle and with 370 food and water available ad libitum. All the animal experiments and protocols were approved by the Institutional Animal Care and Use Committee of SingHealth (IACUC

372 SingHealth \# 2013/SHS/816) and of NTU Singapore (A0373).

\section{Islet isolation, dispersion and cell culture}

375 Mouse pancreatic islets were isolated by perfusing the pancreas through the common 376 bile duct with collagenase as previously described (50). The isolated islets were 377 dispersed into single cells by incubation with Accutase $^{\circledR}$ at $37^{\circ} \mathrm{C}$ for $3-5$ min. The 378 primary islet cells were cultured in CMRL medium supplemented with $10 \%$ heat379 inactivated fetal bovine serum (FBS), $100 \mathrm{U} / \mathrm{ml}$ penicillin and $100 \mu \mathrm{g} / \mathrm{ml}$ streptomycin. 380 MIN6 cells (passages 30-35) were cultured in DMEM containing 10\% heat-inactivated 381 fetal bovine serum, $25 \mathrm{mM}$ glucose, $4 \mathrm{mM}$ L-glutamine, $100 \mathrm{U} / \mathrm{ml}$ penicillin, $100 \mathrm{\mu g} / \mathrm{ml}$ streptomycin and $50 \mu \mathrm{M} 2$-mercaptoethanol. Cells were maintained at $37^{\circ} \mathrm{C}$ under $5 \%$

$383 \mathrm{CO} 2$ and $95 \%$ air. Transient transfections of MIN6 were performed using 
384 Lipofectamine 2000 (ThermoFisher Scientific) according to the manufacturer's instructions. FFAs (palmitate, stearate, oleate and palmitoleate) were conjugated with FFA-free BSA at a 2:1 molar ratio and used at a final concentration of $300 \mu \mathrm{M}$.

\section{Protein extraction and immunoblotting assays}

389 Cells and isolated islets were lysed in RIPA buffer supplemented with protease 390 inhibitor cocktail. Proteins were separated by SDS-PAGE and transferred onto 391 nitrocellulose membranes. Blocking was performed at room temperature for $1 \mathrm{~h}$ in Trisbuffered saline (TBS) with $5 \%$ non-fat milk, followed by incubation with the different 393 primary antibodies (described above) in blocking buffer for either $1 \mathrm{~h}$ at room 394 temperature or overnight at $4{ }^{\circ} \mathrm{C}$. After several washes with TBS containing $0.5 \%$ Tween 20 (TBST), the membranes were incubated with secondary antibodies of antimouse/rabbit IgG/HRP (as appropriate) in TBS with 1\% non-fat milk. Following several washes, the protein bands were visualized using enhanced chemiluminescence (Cell Signaling Technology) and quantified using ImageJ.

399

\section{RNA extraction and quantitative RT-PCR}

401 Total RNA was prepared from tissues or cells using the NucleoSpin RNA II kit 402 (Macherey-Nagel), or prepared from the isolated islets using the NucleoSpin RNA XS 403 kit (Macherey-Nagel). 1 ug of RNA was reversely transcribed using High Capacity 404 cDNA Reverse Transcription Kit (Applied Biosystems) according to the manufacturer's 405 instructions. Real-time PCR was performed on QuantStudio 6 Flex Real-Time PCR 406 System (Applied Biosystems) using Power SYBR Green PCR Master Mix (Applied 407 Biosystems). The PCR primers used are summarized in Supplementary Table 3. 
409 RNA-seq library preparation and data processing

410 Pancreatic islets were isolated from 12-week old wild type (WT) and $\beta$-cell specific

411 FIT2 knockout ( $\beta-F I T 2 K O, K O)$ mice in quintuplicate. Isolated pancreatic islets then

412 cultured in complete CMRL medium overnight for recovery. Total RNA was harvested

413 using RNeasy Plus Mini Kit (Qiagen) followed by RNA-seq library construction. Genes

414 were considered to be significantly differentially expressed when false discovery rate

$415(F D R) \leq 0.05$, with FPKM $\geq 1$ in one sample group retained for subsequent analysis.

416 GO clustering enrichment analysis was carried out on differential genes using the

417 Functional Annotation tool in DAVID version $6.8(51,52)$ under medium stringency for

418 all default annotation categories except protein domains. We identified significant

419 clustered groups having group enrichment scores of $\geq 1.3$, with higher scores

420 indicative of more significant annotated GO clusters. Heatmaps were generated with

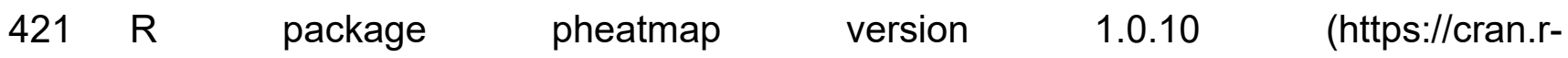

422 project.org/web/packages/pheatmap/index.html).

424 Immunofluorescence

425 Cryosections of $10 \mu \mathrm{m}$ thickness from fixed and cryopreserved pancreas were used

426 for immunofluorescence analysis. Sections were rinsed with TBS, permeabilized, and

427 blocked with $10 \%$ normal goat serum plus $0.2 \%$ Triton $\mathrm{X}-100$ in TBS for $1 \mathrm{~h}$ at room

428 temperature and then incubated overnight with primary antibodies at $4^{\circ} \mathrm{C}$ in a

429 humidified atmosphere. After gentle washing with TBS and incubating with

430 fluorescence secondary antibodies for $1 \mathrm{~h}$ at room temperature, sections were

431 mounted with Vecta Mount solution (Vector Labs) and multiple Z-stack images were

432 obtained using confocal imaging (Leica) and subsequently quantified using Image-J).

433 Briefly, the average fluorescence intensity of the staining, within insulin-positive ROI, 
434 was quantified, corrected by subtraction of average background intensity, and

435 normalized to its control. For LD staining, cryosections were stained with BODIPY 493/503 $(0.01 \mathrm{mg} / \mathrm{ml})$ and DAPI $(5 \mu \mathrm{g} / \mathrm{ml})$ for $15 \mathrm{~min}$ at RT. For propidium iodide (PI)

437 staining, cells were incubated with $10 \mu \mathrm{g} / \mathrm{ml} \mathrm{PI}$ and $5 \mu \mathrm{g} / \mathrm{ml} \mathrm{DAPI}$ in medium for $1 \mathrm{~h}$ at

$43837^{\circ} \mathrm{C}$ followed by RT fixation. Images were captured using a SP8 confocal microscope

439 (Leica). BODIPY-positive puncta per cell and percentage of PI-positive cells were quantified using Image-J Prism 7 (GraphPad).

441

\section{Total islet and pancreatic insulin content}

443 To determine islet insulin content, 10 isolated islets were washed twice with ice-cold

444 D-PBS and then lysed with RIPA buffer. Insulin and protein content of the lysate were 445 measured using Mouse Insulin ELISA (Mercodia) and BCA assay (ThermoFisher 446 Scientific), respectively. Total islet insulin content was normalized to total protein 447 content. To determine pancreatic insulin content, half of the whole pancreas was 448 collected and placed into $5 \mathrm{ml}$ Acid-Ethanol solution $(1.5 \% \mathrm{HCl}$ in $70 \% \mathrm{EtOH})$ overnight 449 at $-20^{\circ} \mathrm{C}$. Tissue was then homogenized and incubated in the same solution overnight 450 at $-20^{\circ} \mathrm{C}$. Supernatant was collected by centrifugation at $3000 \times \mathrm{g}$ for $10 \mathrm{~min}$ at $4^{\circ} \mathrm{C}$, 451 followed by neutralization with $1 \mathrm{M}$ Tris $\mathrm{pH} 7.5$ at $1: 1$ ( $\mathrm{vol} / \mathrm{vol})$. Insulin and protein 452 content of the neutralized solution were measured. Total pancreatic insulin content 453 was normalized by total protein content.

\section{Glucose Stimulated Insulin Secretion (GSIS)}

456 MIN6 cells were pre-incubated at $37^{\circ} \mathrm{C}$ for $2 \mathrm{~h}$ in Krebs Ringer Bicarbonate (KRBH) 457 buffer (119 mM NaCl, $4.74 \mathrm{mM} \mathrm{KCl}, 2.54 \mathrm{mM} \mathrm{CaCl}_{2}, 1.19 \mathrm{mM} \mathrm{MgCl}$, $1.19 \mathrm{mM}$ $458 \mathrm{KH}_{2} \mathrm{PO}_{4}, 25 \mathrm{mM} \mathrm{NaHCO}_{3}$, and $10 \mathrm{mM}$ HEPES, 0.1\% BSA, $0.1 \mathrm{mM}$ glucose, pH 7.4). 
459 At experiment start, fresh $\mathrm{KRBH}$ was added for $30 \mathrm{~min}$, followed by $25 \mathrm{mM}$ glucose

$460 \mathrm{KRBH}$ at $37^{\circ} \mathrm{C}$ for another $30 \mathrm{~min}$. The supernatant was collected for insulin

461 measurements and normalized to total protein. Isolated islets were $2 \mathrm{~h}$ pre-incubated

462 with buffer $\left(125 \mathrm{mM} \mathrm{NaCl}, 5.9 \mathrm{mM} \mathrm{KCl}, 2.56 \mathrm{mM} \mathrm{CaCl}_{2}, 1.2 \mathrm{mM} \mathrm{MgCl}\right.$, $25 \mathrm{mM}$

463 HEPES, $0.1 \%$ BSA and $2.8 \mathrm{mM}$ glucose, $\mathrm{pH} 7.4)$ at $37^{\circ} \mathrm{C} .50$ islets were placed

464 between two layers of bio-gel (Bio-Rad) in a perifusion chamber and perifused at a

465 flow rate of $200 \mu \mathrm{L} / \mathrm{min}$, at $37^{\circ} \mathrm{C}$, for $20 \mathrm{~min}$ prior to the start of sample collection. Islets

466 were perifused for 10 min with $2.8 \mathrm{mM}$ glucose buffer, followed by 10 min with 16.7

$467 \mathrm{mM}$ glucose buffer. At the end of the perifusion, islets were lysed in RIPA buffer and

468 total insulin content was measured for normalization. For in vivo GSIS, mice were

469 starved for $6 \mathrm{~h}$ and blood samples were collected from tail vein to determine basal

470 insulin levels. Mice were then injected with $3 \mathrm{~g}$ glucose $/ \mathrm{kg}$ of body weight,

471 intraperitoneally. Blood samples were collected from the tail vein 15 min after glucose

472 injection. Total blood was centrifuged at $10,000 \times g$ for $10 \mathrm{~min}$ and the supernatant

473 (serum) was collected for insulin measurements using Mouse Insulin ELISA 474 (Mercodia).

475

476 Insulin and glucose tolerance tests

477 Prior to GTT or ITT, mice were fasted for $6 \mathrm{~h}$ with ad libitum access to water and then 478 administered glucose $(2 \mathrm{~g} / \mathrm{kg})$ or insulin (0.75 unit $/ \mathrm{kg})$ intraperitoneally. Blood glucose 479 was measured in blood samples collected from tail vein using a glucometer (Accu480 Chek Performa Nano System). 
483 Pancreatic islets were resuspended in $100 \mu \mathrm{L}$ of butanol/methanol (1:1, v:v) spiked 484 with $66.07 \mathrm{nM}$ of C8 Ceramide (d18:1/8:0) purchased from Avanti Polar Lipids 485 (860508). The cells were sonicated for $30 \mathrm{~min}$ followed by centrifugation at $14,000 \mathrm{~g}$ 486 for $10 \mathrm{~min}$ at $22{ }^{\circ} \mathrm{C}$. The supernatant was transferred to MS vials for analysis. The 487 samples were analysed using an Agilent 1290 series UHPLC system connected to an 488 Agilent $6495 \mathrm{QQQ}$ mass spectrometer after separation on a ZORBAX Eclipse plus 489 C18 column $(2.1 \times 50 \mathrm{~mm}, 1.8 \mu \mathrm{m}, 95 \AA$, Agilent $)$ at $40{ }^{\circ} \mathrm{C}$. The injection volume was

491 formate; solvent B consisted of $90 \%$ isopropanol $/ 10 \%$ acetonitrile (v/v) with $10 \mathrm{mM}$ 492 ammonium formate. The gradient started with a flow rate of $0.4 \mathrm{~mL} / \mathrm{min}$ at $20 \% \mathrm{~B}$ and 493 increased to $60 \% \mathrm{~B}$ at $2 \mathrm{~min}, 100 \% \mathrm{~B}$ at $7 \mathrm{~min}$, held at $100 \% \mathrm{~B}$ until $9 \mathrm{~min}$, followed 494 by equilibration with $20 \%$ B from $9.01 \mathrm{~min}$ until $10.8 \mathrm{~min}$. The column effluent was 495 introduced to the Agilent 6495 QQQ mass spectrometer via AJS-ESI ion source 496 operating under the following conditions: Gas temperature, $200^{\circ} \mathrm{C}$; gas flow, $14 \mathrm{~L} / \mathrm{min}$; 497 nebulizer, $20 \mathrm{psi}$; sheath gas temperature, $250^{\circ} \mathrm{C}$; sheath gas flow, $11 \mathrm{~L} / \mathrm{min}$; capillary, $4983500 \mathrm{~V}$. Mass spectrometry analysis was performed in positive ion mode with dynamic 499 scheduled multiple reaction monitoring (dMRM). Mass spectrometry settings, LC-MS 500 gradient and MRM transitions for each lipid class were adapted from a previously 501 published method (53). Data analysis was performed on Agilent MassHunter 502 Quantitative analysis software. Relative quantitation was based on one-point 503 calibration with Ceramide d18:1/8:0. The data were further normalized to the total 504 number of islets in each sample.

505

506 Co-immunoprecipitation assay for FIT2-MARCH6 interaction 
507 MIN6 cells, transiently co-transfected with pcDNA3.1-FIT2/V5-His and GFP-tagged

508 MARCH6 (BC059190) Mouse Tagged ORF Clone (Origene), were pre-treated with 10

$509 \mu \mathrm{M}$ MG132 (Cell Signaling Technology) for $2 \mathrm{~h}$ and subsequently treated with $300 \mu \mathrm{M}$

510 palmitate (BSA-conjugated) for $6 \mathrm{~h}$. Cells were then lysed in IP lysis buffer

511 (ThermoFisher Scientific), supplemented with protease inhibitor cocktail. Co-

512 immunoprecipitation assay was then performed on the protein lysates using Pierce ${ }^{\mathrm{TM}}$

513 Classic IP Kit (ThermoFisher Scientific) with either Anti-6X His tag antibody (Abcam)

514 or Rabbit IgG (Cell Signaling Technology) in accordance with the manufacturer's

515 instructions. The eluted fraction was then subjected to immunoblotting assay and

516 MARCH6 was detected using Mouse monoclonal turboGFP antibody (Origene).

\section{S-Palmitoylation assay}

519 MIN6 cells, transiently transfected with pcDNA3.1-FIT2/V5-His, were pre-treated with $52010 \mu \mathrm{M}$ MG132 (Cell Signaling Technology) for $2 \mathrm{~h}$ and thereafter treated with $300 \mu \mathrm{M}$

521 palmitate (BSA-conjugated) for $6 \mathrm{~h}$. S-palmitoylation assay was then performed using

522 CAPTUREome ${ }^{\mathrm{TM}}$ S-Palmitoylated Protein Kit (Badrilla) in accordance with

523 manufacturer's instruction. Briefly, cell lysis and free thiol blocking (blocking of free

524 thiols on non-palmitoylated cysteine residue) was performed by incubating cells with

525 the provided lysis buffer for $4 \mathrm{~h}$ with constant shaking. Proteins were then precipitated

526 using acetone, and subsequently resuspended in the provided binding buffer. $30 \mu$ of

527 resuspended proteins were collected as the Input Fraction (IF), while the remainder 528 was split into two tubes: "experimental" and "negative control". In the experimental 529 tube, proteins were treated with thioester cleavage reagent, which cleaves off acyl 530 groups from the protein, resulting in the exposure of a free thiol group. Treated 531 samples were then subjected to CAPTUREome ${ }^{\mathrm{TM}}$ resin for $2.5 \mathrm{~h}$ at room temperature, 
532 where proteins with free thiols were captured by the resin. $50 \mu$ l of flowthroughs were

533 collected as the cleaved unbound fraction (cUF). S-acylated proteins, which were

534 captured by the CAPTUREome ${ }^{\mathrm{TM}}$ resin, were eluted by incubating the resin in $50 \mu \mathrm{l}$ of

$5352 x$ laemmli buffer at $60^{\circ} \mathrm{C}$ for 10 min (cleaved Bound Fraction (cBF)). In the negative

536 control tube, proteins were treated with acyl-preservation reagent, which preserves

537 acyl groups on the protein. Treated samples were then subjected to CAPTUREome ${ }^{\mathrm{TM}}$

538 resin for $2.5 \mathrm{~h}$ at room temperature. $50 \mu \mathrm{l}$ of flowthroughs were collected as preserved

539 unbound fraction (pUF). Proteins were eluted from the CAPTUREome ${ }^{\mathrm{TM}}$ resin by

540 incubation of resin with $50 \mu \mathrm{l}$ of $2 x$ laemmli buffer at $60^{\circ} \mathrm{C}$ for $10 \mathrm{~min}$ (preserved Bound

541 Fraction (pBF)).

542

543 Statistical analysis

544 Data tested for normality (Shapiro-Wilk test) are expressed as mean \pm SEM.

545 Parametric analysis (using Student's t-test) was used to determine statistical

546 difference and $P$ values $<0.05$ were considered as statistically significant (Prism 7 ,

547 GraphPad).

548

DATA AVAILABILITY

550

551 RNA sequencing data reported in this paper is available at NCBI GEO Accession no.:

552 GSE133939. All data mentioned in this paper will be placed on a data repository.

553 Authors declare no primary datasets and computer codes linked to this study.

554

555 ACKNOWLEDGMENTS

556 
557 The mouse pancreatic $\beta$-cell line MIN6 was kindly provided by Dr. Jun-ichi Miyazaki,

558 Osaka University, Japan. This work was supported by the Singapore Ministry of

559 Education under its Singapore Ministry of Education Academic Research Fund Tier 2 560 and Tier 1 (MOE2015-T2-2-087 and 2017-T1-001-220, 2019-T1-001-059) (Y.A.) and 561 the Lee Kong Chian School of Medicine, Nanyang Technological University Singapore 562 Start-up Grant (to Y.A. and P.O.B.) This work is also partly supported by the 563 LKCMedicine Healthcare Research Fund (Diabetes Research), established through 564 the generous support of alumni of Nanyang Technological University, Singapore. C.H. 565 is supported by the Lee Kong Chian School of Medicine and the Nanyang President's 566 Graduate Scholarship, Nanyang Technological University, Singapore. J.N.F. is 567 supported by the Singapore National Research Foundation Fellowship (NRF568 NRFF2016-03). Work in M.R.W. and F.T. laboratory is supported by grants from the 569 National University of Singapore via the Life Sciences Institute (LSI), the National 570 Research Foundation (NRF, NRFI2015-05 and NRFSBP-P4) and the NRF and 571 A*STAR IAF-ICP I1901E0040. P.O.B. is additionally supported by the Swedish 572 Research Council, the Family Erling-Persson Foundation, the Novo Nordisk 573 Foundation, the Stichting af Jochnick Foundation, the Swedish Diabetes Association, 574 the Scandia Insurance Company Ltd., Diabetes Research and Wellness Foundation, 575 Berth von Kantzow's Foundation, the Strategic Research Program in Diabetes at 576 Karolinska Institutet, the ERC-“Advanced Grant” (EYELETS), and the Center of

577 Excellence-International Collaboration Initiative Grant (China). X.Z. is currently 578 supported by the National Natural Science Foundation of China (82070846). The 579 authors would also like to thank the A*STAR Microscopy Platform (Singapore) for 580 assistance in sample processing and for the electron microscopy analysis in this study. 


\section{CONTRIBUTIONS}

583

584 X.Z. and Y.A. designed the study and wrote the manuscript. D.S. and P.O.B. provided

585 input on floxed-FIT2 mice studies. X.Z, C.H, M.C., S.M. and O.S. performed the

586 experiments. E.G.C., M.M.L. and J.N.F. analysed the RNA-sequencing data. C.H.,

587 D.S., J.N.F., P.O.B., F.T., M.R.W. and Y.A. edited the manuscript.

588

589 COMPETING INTEREST

590

$591 \quad$ None 


\section{REFERENCES}

1. de Vries JE, Vork MM, Roemen TH, de Jong YF, Cleutjens JP, van der Vusse GJ, et al. Saturated but not mono-unsaturated fatty acids induce apoptotic cell death in neonatal rat ventricular myocytes. J Lipid Res. 1997;38(7):1384-94.

2. Ulloth JE, Casiano CA, De Leon M. Palmitic and stearic fatty acids induce caspase-dependent and -independent cell death in nerve growth factor differentiated PC12 cells. J Neurochem. 2003;84(4):655-68.

3. Lockridge JB, Sailors ML, Durgan DJ, Egbejimi O, Jeong WJ, Bray MS, et al. Bioinformatic profiling of the transcriptional response of adult rat cardiomyocytes to distinct fatty acids. J Lipid Res. 2008;49(7):1395-408.

4. Hardy S, Langelier Y, Prentki M. Oleate activates phosphatidylinositol 3-kinase and promotes proliferation and reduces apoptosis of MDA-MB-231 breast cancer cells, whereas palmitate has opposite effects. Cancer Res. 2000;60(22):6353-8.

5. Unger RH, Zhou YT. Lipotoxicity of beta-cells in obesity and in other causes of fatty acid spillover. Diabetes. 2001;50 Suppl 1:S118-21.

6. Cnop M, Hannaert JC, Hoorens A, Eizirik DL, Pipeleers DG. Inverse relationship between cytotoxicity of free fatty acids in pancreatic islet cells and cellular triglyceride accumulation. Diabetes. 2001;50(8):1771-7.

7. Martin S, Parton RG. Lipid droplets: a unified view of a dynamic organelle. Nat Rev Mol Cell Biol. 2006;7(5):373-8.

8. Walther TC, Farese RV, Jr. The life of lipid droplets. Biochim Biophys Acta. 2009;1791(6):459-66.

9. Beller M, Thiel K, Thul PJ, Jackle H. Lipid droplets: a dynamic organelle moves into focus. FEBS Lett. 2010;584(11):2176-82.

10. Welte MA. Expanding roles for lipid droplets. Curr Biol. 2015;25(11):R470-81.

11. Bosch M, Sanchez-Alvarez M, Fajardo A, Kapetanovic R, Steiner B, Dutra F, et al. Mammalian lipid droplets are innate immune hubs integrating cell metabolism and host defense. Science. 2020;370(6514).

12. Olzmann JA, Carvalho P. Dynamics and functions of lipid droplets. Nat Rev Mol Cell Biol. 2019;20(3):137-55.

13. Henne WM, Reese ML, Goodman JM. The assembly of lipid droplets and their roles in challenged cells. EMBO J. 2018;37(12).

14. Chen X, Goodman JM. The collaborative work of droplet assembly. Biochim Biophys Acta Mol Cell Biol Lipids. 2017;1862(10 Pt B):1205-11.

15. Choudhary V, Ojha N, Golden A, Prinz WA. A conserved family of proteins facilitates nascent lipid droplet budding from the ER. J Cell Biol. 2015;211(2):261-71.

16. Tong X, Dai C, Walker JT, Nair GG, Kennedy A, Carr RM, et al. Lipid Droplet Accumulation in Human Pancreatic Islets Is Dependent On Both Donor Age and Health. Diabetes. 2020;69(3):342-54.

17. Kadereit B, Kumar P, Wang WJ, Miranda D, Snapp EL, Severina N, et al. Evolutionarily conserved gene family important for fat storage. Proceedings of the National Academy of Sciences of the United States of America. 2008;105(1):94-9.

18. Gross DA, Zhan C, Silver DL. Direct binding of triglyceride to fat storageinducing transmembrane proteins 1 and 2 is important for lipid droplet formation. Proceedings of the National Academy of Sciences of the United States of America. 2011;108(49):19581-6.

19. Goh VJ, Tan JS, Tan BC, Seow C, Ong WY, Lim YC, et al. Postnatal Deletion of Fat Storage-inducing Transmembrane Protein 2 (FIT2/FITM2) Causes Lethal Enteropathy. J Biol Chem. 2015;290(42):25686-99. 
20. Miranda DA, Koves TR, Gross DA, Chadt A, Al-Hasani H, Cline GW, et al. Repatterning of skeletal muscle energy metabolism by fat storage-inducing transmembrane protein 2. J Biol Chem. 2011;286(49):42188-99. 21. Miranda DA, Kim JH, Nguyen LN, Cheng W, Tan BC, Goh VJ, et al. Fat Storage-inducing Transmembrane Protein 2 Is Required for Normal Fat Storage in Adipose Tissue. J Biol Chem. 2014;289(14):9560-72.

648 22. Hayes M, Choudhary V, Ojha N, Shin JJ, Han GS, Carman GM, et al. Fat storage-inducing transmembrane (FIT or FITM) proteins are related to lipid phosphatase/phosphotransferase enzymes. Microb Cell. 2017;5(2):88-103.

23. Becuwe M, Bond LM, Pinto AFM, Boland S, Mejhert N, Elliott SD, et al. FIT2 is an acyl-coenzyme A diphosphatase crucial for endoplasmic reticulum homeostasis. J Cell Biol. 2020;219(10). 24. Yap WS, Shyu P, Jr., Gaspar ML, Jesch SA, Marvalim C, Prinz WA, et al. The yeast FIT2 homologs are necessary to maintain cellular proteostasis and membrane lipid homeostasis. Journal of cell science. 2020;133(21).

25. Wicksteed B, Brissova M, Yan W, Opland DM, Plank JL, Reinert RB, et al. Conditional gene targeting in mouse pancreatic ss-Cells: analysis of ectopic Cre transgene expression in the brain. Diabetes. 2010;59(12):3090-8.

660

661

26. Lee JY, Ristow M, Lin X, White MF, Magnuson MA, Hennighausen L. RIP-Cre revisited, evidence for impairments of pancreatic beta-cell function. J Biol Chem. 2006;281(5):2649-53.

663 27. Kharroubi I, Ladriere L, Cardozo AK, Dogusan Z, Cnop M, Eizirik DL. Free fatty acids and cytokines induce pancreatic beta-cell apoptosis by different mechanisms: role of nuclear factor-kappaB and endoplasmic reticulum stress. Endocrinology. 2004;145(11):5087-96.

28. Elouil H, Bensellam M, Guiot $Y$, Vander Mierde D, Pascal SM, Schuit FC, et al. Acute nutrient regulation of the unfolded protein response and integrated stress response in cultured rat pancreatic islets. Diabetologia. 2007;50(7):1442-52.

29. Manukyan L, Ubhayasekera SJ, Bergquist J, Sargsyan E, Bergsten P. Palmitate-induced impairments of beta-cell function are linked with generation of specific ceramide species via acylation of sphingosine. Endocrinology. 2015;156(3):802-12.

30. Wang F, Song W, Brancati G, Segatori L. Inhibition of endoplasmic reticulumassociated degradation rescues native folding in loss of function protein misfolding diseases. J Biol Chem. 2011;286(50):43454-64.

31. Carvalho P, Goder V, Rapoport TA. Distinct ubiquitin-ligase complexes define convergent pathways for the degradation of ER proteins. Cell. 2006;126(2):361-73.

32. Xie Y, Zheng Y, Li H, Luo X, He Z, Cao S, et al. GPS-Lipid: a robust tool for the prediction of multiple lipid modification sites. Sci Rep. 2016;6:28249.

33. Draper JM, Smith CD. Palmitoyl acyltransferase assays and inhibitors (Review). Mol Membr Biol. 2009;26(1):5-13.

34. Chorlay A, Monticelli L, Verissimo Ferreira J, Ben M'barek K, Ajjaji D, Wang S, et al. Membrane Asymmetry Imposes Directionality on Lipid Droplet Emergence from the ER. Dev Cell. 2019;50(1):25-42 e7.

35. Wojtczak L, Schonfeld P. Effect of fatty acids on energy coupling processes in mitochondria. Biochim Biophys Acta. 1993;1183(1):41-57.

36. Hruz T, Laule O, Szabo G, Wessendorp F, Bleuler S, Oertle L, et al. Genevestigator v3: a reference expression database for the meta-analysis of transcriptomes. Adv Bioinformatics. 2008;2008:420747. 
bioRxiv preprint doi: https://doi.org/10.1101/2021.02.28.433270; this version posted February 28, 2021. The copyright holder for this preprint (which was not certified by peer review) is the author/funder, who has granted bioRxiv a license to display the preprint in perpetuity. It is made available under aCC-BY 4.0 International license.

691 37. Levy M, Futerman AH. Mammalian ceramide synthases. IUBMB Life. 2010;62(5):347-56.

693

694

695

38. Mullen TD, Hannun YA, Obeid LM. Ceramide synthases at the centre of sphingolipid metabolism and biology. Biochem J. 2012;441(3):789-802.

39. Aflaki E, Doddapattar P, Radovic B, Povoden S, Kolb D, Vujic N, et al. C16 ceramide is crucial for triacylglycerol-induced apoptosis in macrophages. Cell Death Dis. 2012;3:e280.

697

698

699

40. Summers SA. Ceramides in insulin resistance and lipotoxicity. Prog Lipid Res. 2006;45(1):42-72.

700 41. Veret J, Coant N, Berdyshev EV, Skobeleva A, Therville N, Bailbe D, et al. 701 Ceramide synthase 4 and de novo production of ceramides with specific $\mathrm{N}$-acyl chain 702 lengths are involved in glucolipotoxicity-induced apoptosis of INS-1 beta-cells. 703 Biochem J. 2011;438(1):177-89.

704 42. Liu Z, Xia Y, Li B, Xu H, Wang C, Liu Y, et al. Induction of ER stress-mediated 705 apoptosis by ceramide via disruption of $\mathrm{ER} \mathrm{Ca}(2+)$ homeostasis in human adenoid 706 cystic carcinoma cells. Cell Biosci. 2014;4:71.

707 43. Boslem E, Weir JM, Maclntosh G, Sue N, Cantley J, Meikle PJ, et al. Alteration 708

709

710 of endoplasmic reticulum lipid rafts contributes to lipotoxicity in pancreatic beta-cells. J Biol Chem. 2013;288(37):26569-82.

44. Tang T, Abbott MJ, Ahmadian M, Lopes AB, Wang Y, Sul HS. Desnutrin/ATGL activates PPARdelta to promote mitochondrial function for insulin secretion in islet 712 beta cells. Cell Metab. 2013;18(6):883-95.

713 45. Cho YS, Chen CH, Hu C, Long J, Ong RT, Sim X, et al. Meta-analysis of 714 genome-wide association studies identifies eight new loci for type 2 diabetes in east 715 Asians. Nat Genet. 2011;44(1):67-72.

716 46. Blaskovic S, Blanc M, van der Goot FG. What does S-palmitoylation do to membrane proteins? FEBS J. 2013;280(12):2766-74.

47. Chamberlain LH, Shipston MJ. The physiology of protein S-acylation. Physiol Rev. 2015;95(2):341-76.

720 48. Kong C, Lange JJ, Samovski D, Su X, Liu J, Sundaresan S, et al. Ubiquitination 721 and degradation of the hominoid-specific oncoprotein TBC1D3 is regulated by protein 722 palmitoylation. Biochem Biophys Res Commun. 2013;434(2):388-93.

723 49. Adams MN, Harrington BS, He Y, Davies CM, Wallace SJ, Chetty NP, et al. 724 EGF inhibits constitutive internalization and palmitoylation-dependent degradation of 725 membrane-spanning procancer CDCP1 promoting its availability on the cell surface. 726 Oncogene. 2015;34(11):1375-83.

727 50. Li DS, Yuan YH, Tu HJ, Liang QL, Dai LJ. A protocol for islet isolation from mouse pancreas. Nat Protoc. 2009;4(11):1649-52.

51. Huang da W, Sherman BT, Lempicki RA. Bioinformatics enrichment tools: paths toward the comprehensive functional analysis of large gene lists. Nucleic acids research. 2009;37(1):1-13.

732 52. Huang da W, Sherman BT, Lempicki RA. Systematic and integrative analysis 733 of large gene lists using DAVID bioinformatics resources. Nat Protoc. 2009;4(1):44-

735 53. Sieber-Ruckstuhl NS, Burla B, Spoerel S, Schmid F, Venzin C, Cazenave736 Gassiot A, et al. Changes in the Canine Plasma Lipidome after Short- and Long-Term 
742 Fig 1: FA-mediated changes in $\beta$-cell LD numbers relates to FIT2 protein 743 abundance.

744 A, BODIPY staining of lipid droplets in MIN6 cells treated with BSA, oleate or palmitate $745(300 \mu \mathrm{M})$ for $24 \mathrm{~h}$. Lipid droplets stained with BODIPY (green) and nuclei stained with

746 DAPI (blue). Images shown are maximum-intensity projections. Scale bar $=50 \mu \mathrm{m}$. B,

747 Quantitation of BODIPY-positive puncta per cell using Image-J. (>500 cells from 3 748 independent experiments were analyzed per group). C, Representative immunoblot of 749 LD formation proteins after MIN6 cells treated with $300 \mu \mathrm{M}$ of palmitoleate (16:1), 750 oleate (18:1), palmitate (16:0), stearate (18:0) or BSA (control) for 24 h. D, E, 751 Representative immunnoblot and semi-quantitation of FIT2 protein in islets isolated 752 from db/+ and db/db mice (16 wk-old male, $\mathrm{N}=4$ ). F, BODIPY staining of lipid droplets 753 in control (Ctrl shRNA) or FIT2 knockdown (FIT2 shRNA) MIN6 cells treated with BSA 754 or $300 \mu \mathrm{M}$ of oleate for $48 \mathrm{~h}$. Lipid droplets were stained with BODIPY (green) and 755 nuclei were stained with DAPI (blue). Images shown are maximum-intensity 756 projections. Scale bar $=50 \mu \mathrm{m}$. G, Quantitation of BODIPY-positive punctae per cell 757 using Image-J. BSA- treated Control (Ctrl shRNA, blue) or FIT2 knockdown (FIT2 758 shRNA, red) and oleate-treated $(300 \mu \mathrm{M})$ Control (Ctrl shRNA, green) or FIT2 759 knockdown (FIT2 shRNA, purple) (>1000 cells from 3 independent experiments were 760 analyzed per group). H, BODIPY staining of lipid droplets in pancreas sections of chow 761 fed floxed-control (FL, blue) and $\beta F I T 2 K O(K O$, red) and Western Diet (West, 25 wk) 762 fed floxed-control (FL, green) and BFIT2KO (KO, purple). Lipid droplets were 763 visualized using a BODIPY stain (green). $\beta$-cells were stained with insulin (red), and 764 nuclei stained with DAPI (blue). Images shown are maximum-intensity projections. 
765 Scale bar $=25 \mu \mathrm{m}$. I, Quantitation of BODIPY-positive puncta per cell using Image-J

$766(\mathrm{~N}=3, \geq 9$ islets from three mice were analyzed per group). Values shown are mean \pm 767 SEM; *, $\mathrm{P}<0.05 ;{ }^{* *}, \mathrm{P}<0.01 ;{ }^{* * *}, \mathrm{P}<0.001$ relative to control (two-tailed Student's t768 test).

769

770 Fig 2: Glucose homeostasis and $\beta$-cell function is impaired in $\beta F I T 2 K O$ mice.

771 A, IPGTT on chow fed floxed-control (FL, blue) and BFIT2KO (KO, red) or Western

772 Diet (West, 25 wk) fed floxed-control (FL, green) and $\beta F I T 2 K O$ (KO, purple) and B, 773 AUC of blood glucose levels from $\mathrm{A}(\mathrm{N}=6)$. C, ITT on chow fed floxed-control (FL, blue) 774 and $\beta$ FIT2KO (KO, red) or Western Diet (West) fed floxed-control (FL, green) and $775 \beta$ FIT2KO (KO, purple) $\mathbf{D}$, AUC of blood glucose levels from $\mathrm{C}(\mathrm{N}=4)$. $\mathbf{E}$, In vivo insulin secretion following glucose administration (I.P.) in floxed-control (FL) and BFIT2KO

777 (KO) mice (12 wk-old male, N=7). F, Ex vivo islet glucose-stimulated insulin secretion 778 from floxed-control (FL) and $\beta F I T 2 K O(K O)$ mice (12 wk-old male, N=3). G, Area under 779 the curve (AUC) for insulin secretion at $16.7 \mathrm{mM}$ glucose $(16.7 \mathrm{G})$ from $\mathrm{F}(\mathrm{N}=3)$. $\mathbf{H}$, 780 Gene ontology (GO) clustering analysis of down- and up-regulated genes in ( $\beta F I T 2 K O)$ $781 \mathrm{KO}$ as compared to floxed-control (FL) islets $(\mathrm{N}=4)$. Enrichment score of each $\mathrm{GO}$ 782 cluster indicated below respective term, significant terms represented by enrichment 783 score $\geq 1.3$ (Supplementary Table 1). I, Expression of key $\beta$-cell genes in islets from $784 \mathrm{FL}$ and $\mathrm{KO}$ mice extracted from RNA-Seq data in $\mathrm{H}$. Values shown are mean $\pm \mathrm{SEM}$; $785{ }^{*}, \mathrm{P}<0.05 ;{ }^{* *}, \mathrm{P}<0.01 ;{ }^{* *}, \mathrm{P}<0.001$ relative to control (two-tailed Student's t-test).

787 Fig 3: Loss of $\beta$-cell FIT2 exacerbates ER stress and survival.

788 A, C, Representative immunostain for p-IRE1 $\alpha$ and ATF4 (green), insulin (red) and 789 DAPI (blue) in pancreas sections from floxed control (FL) and $\beta F I T 2 K O$ (KO) mice 
treated with either Chow or West diet (25 wk). Images shown are maximum-intensity

791 projections with a scale bar of $50 \mu \mathrm{m}$. B, D, Quantitation of relative fluorescence

792 intensity of $p-I R E 1 \alpha$ and ATF4 staining within insulin-positive cells ( $N=3-5$ mice, $\geq 9$

793 islets from each mouse were analyzed per group). E, Representative immunoblot of

794 indicated proteins in control shRNA transfected or FIT2 stable knockdown MIN6 cells

795 (FIT2 shRNA) in the absence or presence of palmitate (300 $\mu \mathrm{M})$. F, Representative 796 image of control shRNA transfected or FIT2 stable knockdown (FIT2 shRNA) MIN6

797 cells in the absence (BSA only) or presence of palmitate (300 $\mu \mathrm{M}, 24 \mathrm{~h}$ ) stained for

798 DAPI (blue) and Propidium lodide (PI, red). Images shown are maximum-intensity 799 projections. Scale bar $=50 \mu \mathrm{m}$. G, Quantitation of the percentage of PI-positive cells 800 over total number of cells (>1000 cells from 3 independent experiments were analyzed 801 per group). $\mathbf{H}$, Measurements of capase-3/7 activity in control shRNA transfected or FIT2 knockdown (FIT2 shRNA) MIN6 cells in the absence (BSA only) or presence of palmitate $(300 \mu \mathrm{M}, 24 \mathrm{~h})(\mathrm{N}=4)$. I, Quantitation of different ceramide species in islets

804 from 25 wk of west-diet fed floxed mice (FL-west) and $\beta F I T 2 K O$ (KO West) by LC-MS 805 (N=3). J, K, Representative immunoblot and analysis of CHOP in MIN6 cells treated 806 with Fumonisin B1 (FB1) $(10 \mu \mathrm{M})$ in the presence and absence of palmitate $(300 \mu \mathrm{M}$,

4h) $(\mathrm{N}=4)$. Values shown are mean $\pm \mathrm{SEM}$; ns, not significant; ${ }^{* *}, \mathrm{P}<0.01$; ${ }^{* *}, \mathrm{P}<$ $808 \quad 0.001$ relative to control (two-tailed Student's t-test).

809

810 Fig 4: Overexpression of FIT2 in MIN6 cells ameliorates palmitate-induced 811 lipotoxicity.

812 A-G, MIN6 cells were cultured in 6-well plates and transfected with $0.5 \mu$ empty 813 pcDNA3.1 vector (Mock) or pcDNA3.1-FIT2 (FIT2-OE) per well, followed by treatment 814 with BSA or palmitate $(300 \mu \mathrm{M})$ for $24 \mathrm{~h}$. A, B, Representative immunoblot and semi- 
815 quantitation FIT2 protein levels ( $N=4$ independent experiments). C, Lipid droplet

816 staining (BODIDY, green) in vector transfected (Mock) or in FIT2 overexpressing

817 (FIT2-OE) MIN6 cells (nuclei stained with DAPI; blue) in the absence (BSA) and

818 presence of palmitate $(300 \mu \mathrm{M}, 24 \mathrm{~h})$. Images shown are maximum-intensity

819 projections with a scale bar of $50 \mu \mathrm{m}$. D, Quantitation of BODIPY-positive puncta per

820 cell using Image-J. (>1000 cells from 3 independent experiments were analyzed per

821 group). E, Representative immunoblot analysis and F, corresponding semi-

822 quantitation of CHOP levels ( $N=4)$. G, Measurements of capase-3/7 activity in control

823 vector transfected (Mock) or FIT2 overexpressing (FIT2-OE) MIN6 cells in the absence

$824(B S A)$ or presence of palmitate $(300 \mu \mathrm{M})(\mathrm{N}=4)$. Values shown are mean $\pm \mathrm{SEM} ;{ }^{*}, \mathrm{P}$

$825<0.05 ;{ }^{* *}, \mathrm{P}<0.01 ;{ }^{* * *}, \mathrm{P}<0.001$ relative to control (two-tailed Student's t-test).

826

827 Fig 5: Palmitate-induced reduction of FIT2 protein involves palmitoylation and 828 its ERAD-C mediated degradation in MIN6 cells.

829 A-D, Representative immunoblot analysis and semi-quantitation of FIT2 protein in 830 MIN6 cells pre-treated with respective pharmacological inhibitors (10 $\mu$ M MG132 or 10 $831 \mu \mathrm{M} E S, 2 \mathrm{~h}$ ), followed by co-treatment with inhibitors in the presence of palmitate (300 $832 \mu \mathrm{M})$ for $4 \mathrm{~h}(\mathrm{~N}=3)$. E, Representative immunoblot for co-immunoprecipitation (Co-IP) 833 of FIT2 and MARCH6 in MIN6 cells in the absence (BSA) and presence of palmitate 834 (Pal, $300 \mu \mathrm{M}, 6 \mathrm{~h}$ ), following pre-treatment with $10 \mu \mathrm{M}$ MG132 for $2 \mathrm{~h}$. Pull-down of 835 FIT2 using equal amount of input protein was carried out using 6xHis antibody (with 836 isotype control) and thereafter captured proteins were probed for MARCH6 protein 837 using the tGFP antibody. F, Representative immunoblot analysis and G, semi838 quantitation of FIT2 protein from serum-starved MIN6 cells $(2 \mathrm{~h})$ transfected with 839 scrambled siRNA (Ctrl siRNA) or March6 siRNAs, followed by treatment with BSA or 
840 palmitate $(300 \mu \mathrm{M})$ for $4 \mathrm{~h}(\mathrm{~N}=4)$. $\mathrm{H}$, Representative immunoblot of S-palmitoylation

841 assay on both wildtype (WT) and mutant (C7/70/140/251A) FIT2 under steady-state

842 (BSA) and palmitate (Pal, $300 \mu \mathrm{M}, 6 \mathrm{~h}$ ) conditions. The increased S-palmitoylation of

843 FIT2 under palmitate conditions (lane 3, CAPTUREome ${ }^{\mathrm{TM}}$ resin cleaved bound

844 fraction (cBF)) was markedly abrogated in the mutant FIT2. Input fraction (IF) and the

845 flowthrough fraction which represents the cleaved unbound fraction (cUF) were

846 collected and analysed. A separate set of protein lysates (Negative control) was

847 treated with acyl-preservation reagent and subjected to incubation with

848 CAPTUREome ${ }^{\mathrm{TM}}$ resin (Flowthrough fraction was used as the preserved unbound

849 fraction (pUF) while eluted fraction was used as the preserved bound fraction (pBF))

850 I, Representative immunoblot and $\mathbf{J}$, corresponding semi-quantitation of FIT2 protein

851 levels in MIN6 cells pre-treated with Cerulenin $(45 \mu \mathrm{M})$ for $2 \mathrm{~h}$, followed by co-

852 treatment of cerulenin $(45 \mu \mathrm{M})$ in the presence of palmitate $(300 \mu \mathrm{M})$ for $4 \mathrm{~h}(\mathrm{~N}=3)$. $\mathrm{K}$,

853 Representative immunoblot analysis and L, corresponding semi-quantitation of FIT2

854 protein levels in MIN6 cells transfected with pcDNA3.1-FIT2/V5-His (WT) or mutant

$855(\mathrm{C} 7 / 70 / 140 / 251 \mathrm{~A})$ followed by treatment with BSA or palmitate $(300 \mu \mathrm{M})$ for $24 \mathrm{~h}$.

856 Values shown are mean $\pm \mathrm{SEM} ;{ }^{*}, \mathrm{P}<0.05 ;{ }^{* *}, \mathrm{P}<0.01$; ${ }^{* *}, \mathrm{P}<0.001$ relative to

857 control (two-tailed Student's t-test).

858

859 Supplementary Fig 1: Relative levels of LD formation proteins following FA 860 treatment as well as analysis of FIT2 in islets of $\beta$ FIT2KO mice.

861 A-D, Semi-quantitation of immunoblots for FIT2, Seipin, Perilipin2 and CHOP protein 862 levels in MIN6 cells treated with palmitoleate (16:1), oleate (18:1), palmitate (16:0), 863 stearate (18:0) $(300 \mu \mathrm{M}, 24 \mathrm{~h})$ or BSA control $(\mathrm{N}=3-4)$. E, Representative in situ 864 hybridization image for FIT2 mRNA (red) combined with immunohistochemistry for 
865 insulin (green) in pancreatic cryosections from C57BL/6 mice. DAPI was used to counterstain the cell nucleus (blue). Expanded image (right) of the demarcated section.

867 Images shown are maximum-intensity projections. Scale bar $=50 \mu \mathrm{m}$. F, Semi868 quantitation of immunoblot analysis of FIT2 expression in vector only (Ctrl shRNA) or 869 stable FIT2 knockdown (FIT2 shRNA) MIN6 cells treated with or without palmitate (300 $870 \mu \mathrm{M}) . \mathbf{G}$, Representative immunoblot and $\mathbf{H}$, corresponding semi-quantitation of FIT2 871 protein in isolated islets from floxed control (FL) and $\beta F I T 2 K O(K O)$ mice (12 wk-old 872 male, $\mathrm{N}=7$ ). Values shown are mean $\pm \mathrm{SEM}$; ns, not significant; * $\mathrm{P}<0.05$; ${ }^{* *}, \mathrm{P}<$ $8730.01 ;{ }^{* * *}, \mathrm{P}<0.001$ relative to control (two-tailed Student's t-test).

875 Supplementary Fig 2: Extended phenotype description of $\beta F I T 2 K O$ mice.

876 A, Gene expression (qPCR) analysis of FIT2 mRNA levels in pancreatic islets, 877 adipose tissue, liver and hypothalamus of floxed control (FL) and $\beta F I T 2 K O(K O)$ 878 mice (12 wk-old male, N=3-4). B, IPGTT on FL, KO, Rip-Cre and WT mice and C, 879 corresponding area under the curve (AUC) of blood glucose levels (12-16 wk-old 880 male, $\mathrm{N}=10-13)$. D, ITT on FL, KO, Rip-Cre and WT mice and E, corresponding AUC 881 of blood glucose levels (12-16 wk-old male, $\mathrm{N}=7$ ). $\mathbf{H}$, Body weight of floxed control 882 (FL) and $\beta F I T 2 K O(K O)$ fed with chow diet (FL Chow, KO Chow) or West diet (FL 883 West, KO West) for 25 weeks $(\mathrm{N}=6)$. Values shown are mean $\pm \mathrm{SEM} ;{ }^{*}, \mathrm{P}<0.05$; ${ }^{* *}$, $884 \mathrm{P}<0.01 ;{ }^{* * *}, \mathrm{P}<0.001$ relative to control (two-tailed Student's t-test).

886 Supplementary Fig 3: Islet characteristics of $\beta$ FIT2KO mice.

887 A, Representative immunostaining for insulin (red), glucagon (green) and 888 somatostatin (white) in pancreas sections from $\mathrm{FL}$ and $\mathrm{KO}$ mice (12 wk-old male). 889 Scale bar $=50 \mu \mathrm{m} . \mathbf{B}, \mathbf{C}$, Cell-type distribution and $\beta$-cell size analysis of in situ islets 
890 in pancreas sections from floxed control $(F L)$ and $\beta F I T 2 K O(K O)$ mice (12 wk-old male,

$891 \mathrm{~N}=4-5)$. D, $\mathrm{E}$, Measurements of total pancreas $(\mathrm{N}=4)$ and islet $(\mathrm{N}=7)$ insulin content.

892 F, Representative Transmission Electron Microscope (TEM) images of insulin 893 granules of $\mathrm{FL}$ and $\mathrm{KO}$ pancreata $(\mathrm{N}=3)$. Scale bar $=1 \mu \mathrm{m}$. $\mathbf{G}$, ATP/ADP ratio of FL 894 and $\mathrm{KO}$ islets in $2.8 \mathrm{mM}$ glucose $(2.8 \mathrm{G})$ followed by stimulation with $16.7 \mathrm{mM}$ glucose 895 (16.7 G). (N=4). H, Measurements of changes in $\left[\mathrm{Ca}^{2+}\right]$ i in $\mathrm{FL}$ and $\mathrm{KO}$ islets exposed 896 to varying concentrations of glucose " $\mathrm{G}$ " as indicated (15-20 islets from four 897 independent experiments were analyzed per group). I, AUC of $\left[\mathrm{Ca}^{2+}\right] \mathrm{i}$ at $16.7 \mathrm{G}(\mathrm{n}=15-$ 898 20). Values shown are mean \pm SEM; ns, not significant; * $P<0.05 ;{ }^{* *}, P<0.01$; ${ }^{* * *}$, $899 P<0.001$ relative to control (two-tailed Student's t-test).

900

901 Supplementary Fig 4: Relative levels of ER stress proteins and ceramide 902 immunodetection in pancreas of $\beta F I T 2 K O$ mice.

903 A-D, Semi-quantitation of immunoblot analysis of IRE1 $1 \alpha, p-I R E 1 \alpha$, ATF4 and CHOP 904 protein levels in scrambled (Ctrl shRNA) or FIT2 knockdown (FIT2 shRNA) MIN6 cells 905 in the absence $(B S A)$ or presence of palmitate $(300 \mu \mathrm{M})$. E, Representative 906 immunostaining image for insulin (red), ceramide (green) and DAPI (blue) in pancreas 907 sections from 25 wk of western diet fed FL and $\mathrm{KO}$ mice. Scale bar $=50 \mu \mathrm{m}$. F, 908 Quantitation of ceramide fluorescence intensities from floxed control (FL) and $909 \beta F I T 2 K O(K O)$ islets of 25 wk of western diet fed mice (normalised to FL) using Image910 J. Values shown are mean \pm SEM; ns, not significant; ${ }^{*}, \mathrm{P}<0.05 ;{ }^{* *}, \mathrm{P}<0.01 ;{ }^{* * *}, \mathrm{P}$ $911<0.001$ relative to control (two-tailed Student's t-test). 
913 Supplementary Fig 5: Relative changes in gene and protein levels of FIT2

914 following exposure to different FAs and separately on March6 knockdown

915 efficiency in MIN6 cells.

916 A, Relative FIT2 mRNA levels (qPCR) in MIN6 cells treated with BSA or different FAs

$917(300 \mu \mathrm{M})$ for $24 \mathrm{~h}(\mathrm{~N}=3)$. B, MIN6 cells were transiently transfected with a scrambled 918 (ctrl siRNA) or different siRNA oligonucleotides targeting March6. $36 \mathrm{~h}$ after 919 transfection, cells were treated with either BSA or palmitate $(300 \mu \mathrm{M})$ for $4 \mathrm{~h}$. B, 920 Relative March6 gene expression levels following siRNA mediated knockdown. C,

921 Schematic representation of point mutants $(C \rightarrow A)$ of FIT2. D-G, Representative 922 immunoblot analysis and semi-quantification of FIT2 protein levels in MIN6 cells 923 transfected with pcDNA3.1-FIT2/V5-His (WT) or mutant followed by treatment with 924 BSA, palmitate $(300 \mu \mathrm{M})$ or stearate $(300 \mu \mathrm{M})$ for $24 \mathrm{~h}(\mathrm{~N}=3-4)$. Values shown are 925 mean \pm SEM; ns, not significant; *, $\mathrm{P}<0.05 ;{ }^{* *}, \mathrm{P}<0.01$; ${ }^{* *}, \mathrm{P}<0.001$ relative to 926 control (two-tailed Student's t-test). 
A

BODIPY/DAPI
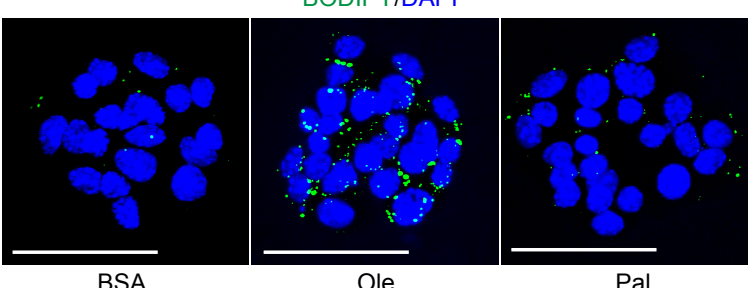

D

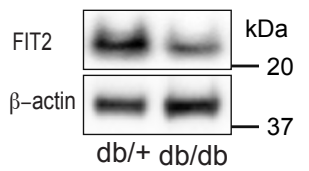

E

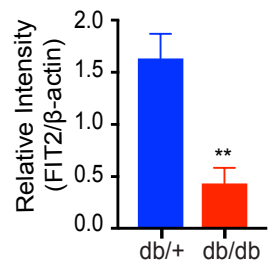

F
B

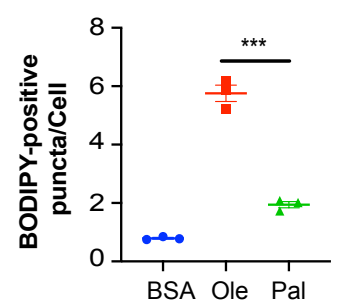

C

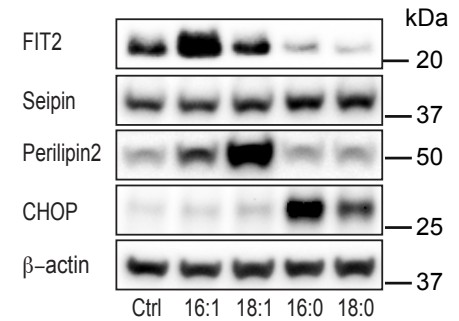

BODIPY/DAPI

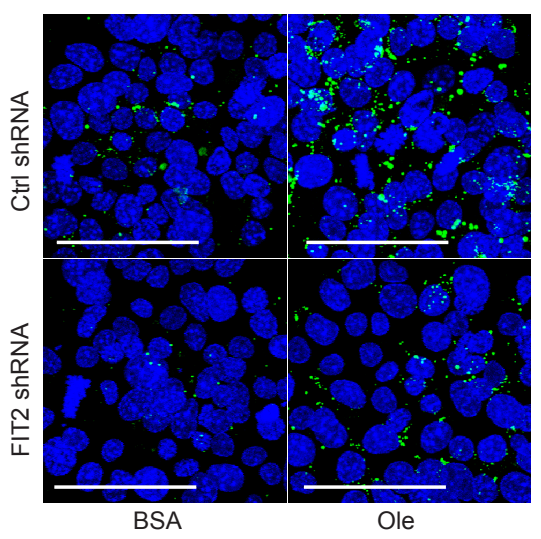

G

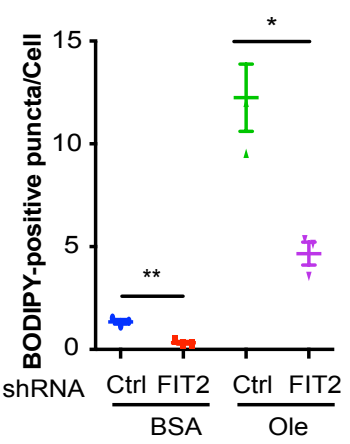

H BODIPY/DAPI/INS
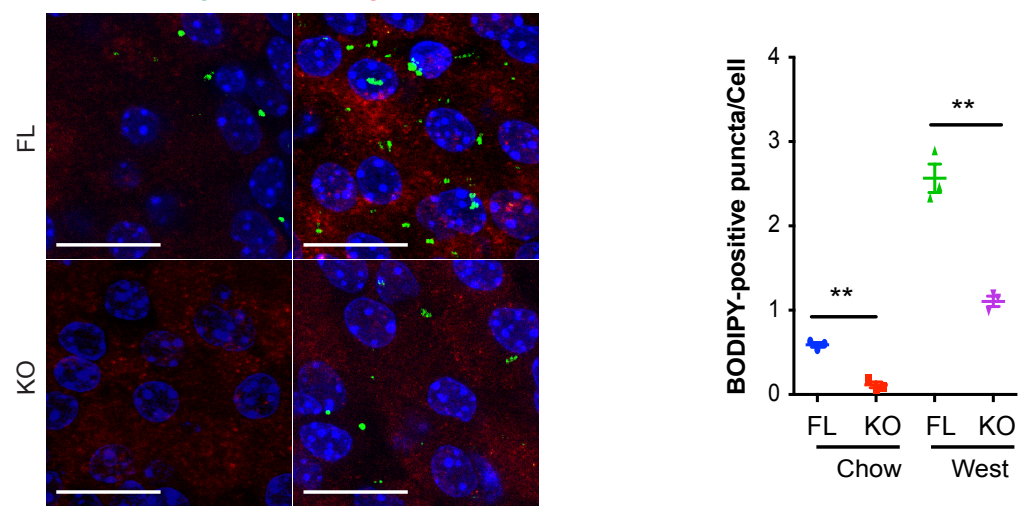

Chow

West 
A

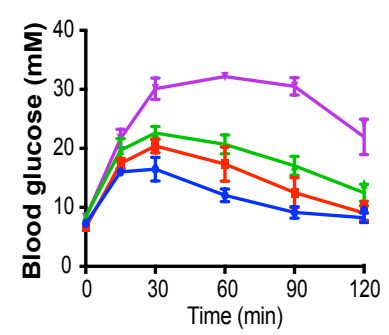

B

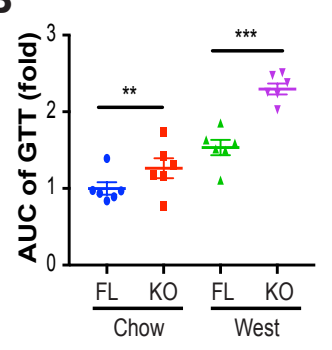

C

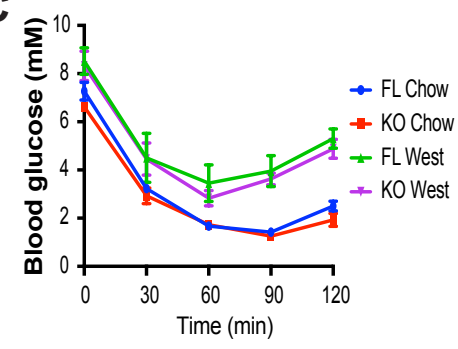

D

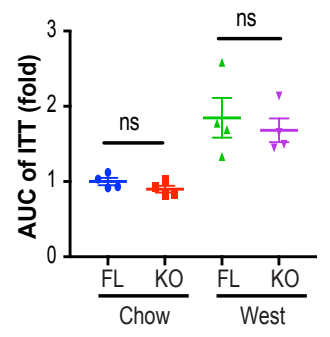

E

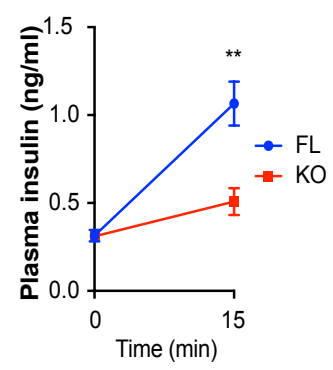

F

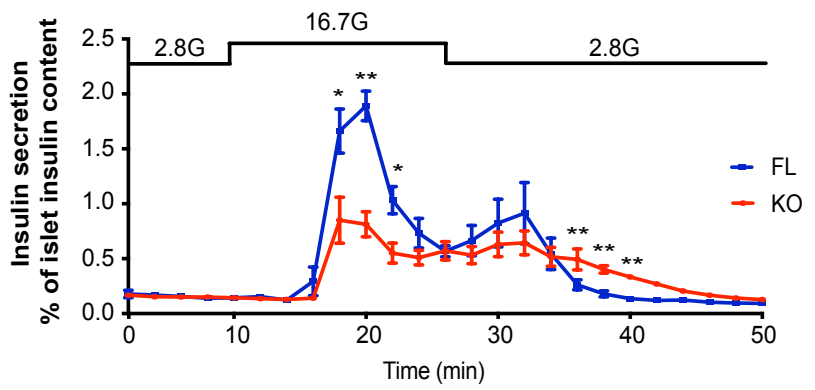

G

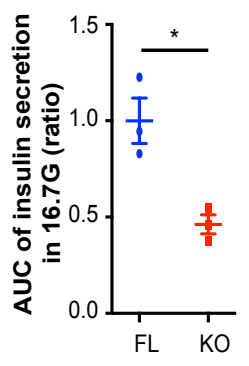

H

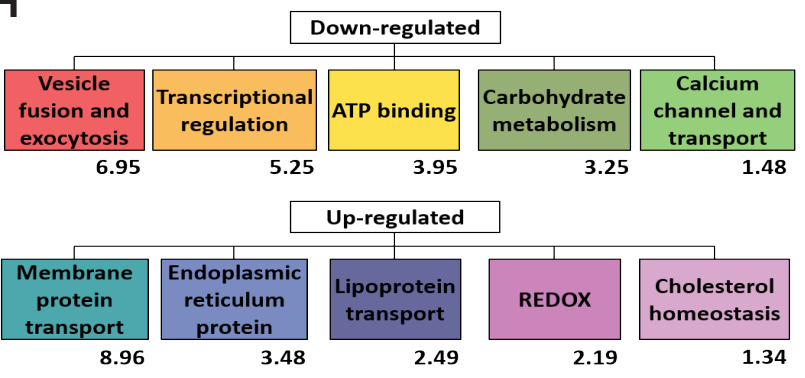

I

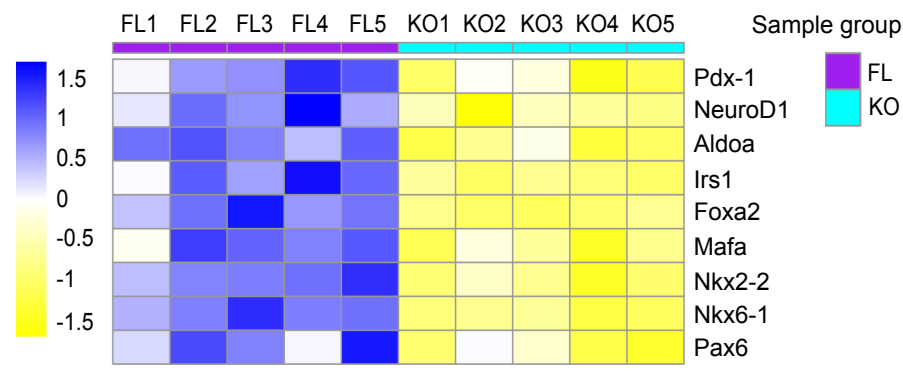



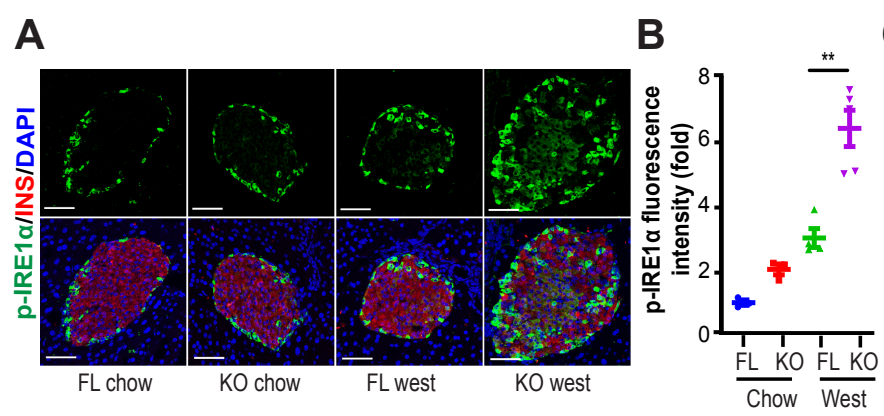

E
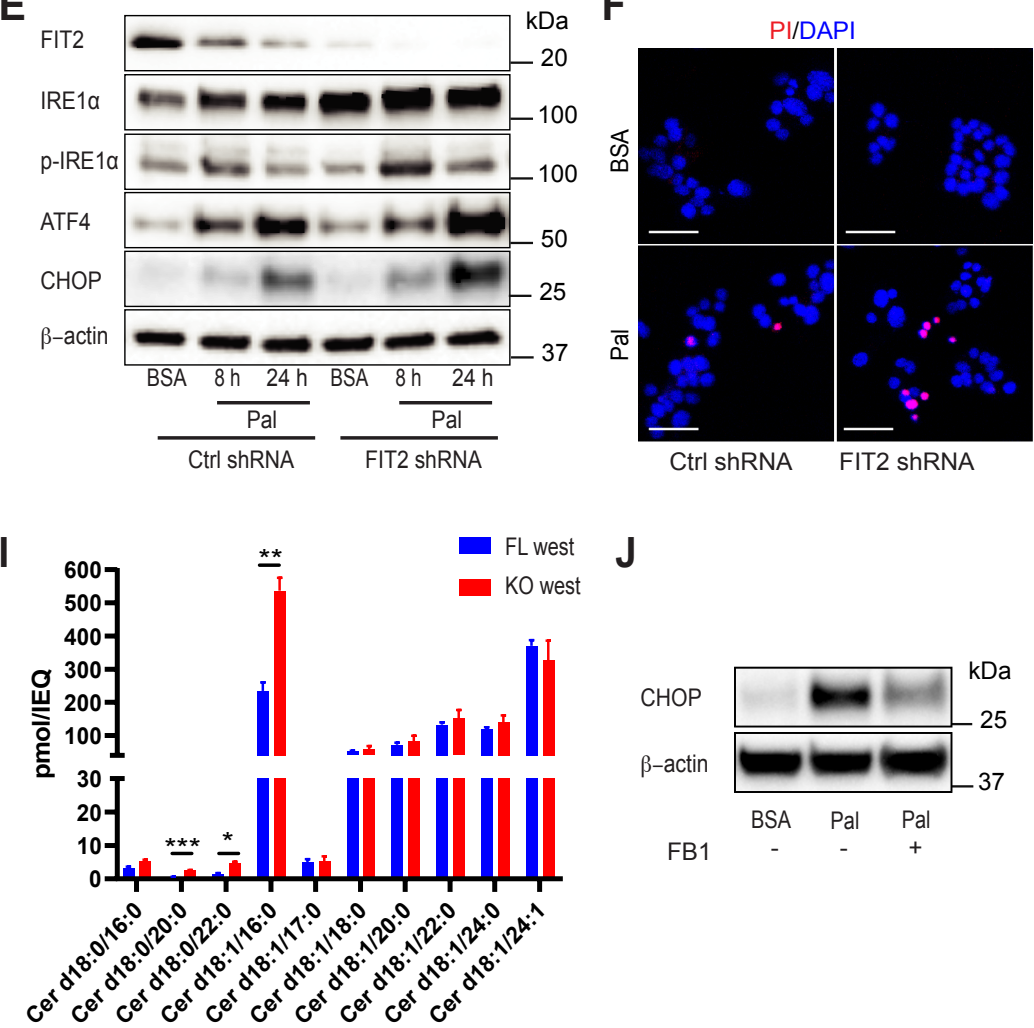

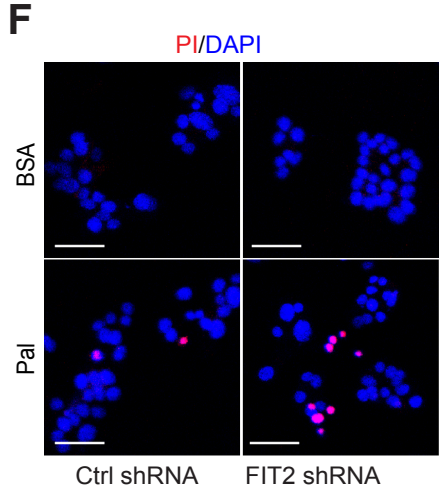

G

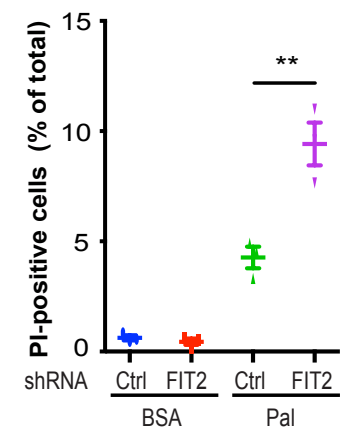

K

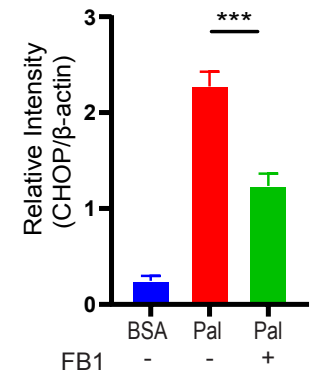

FB1

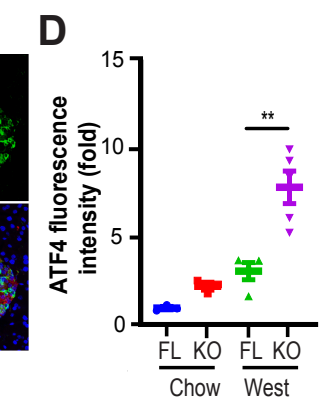

H

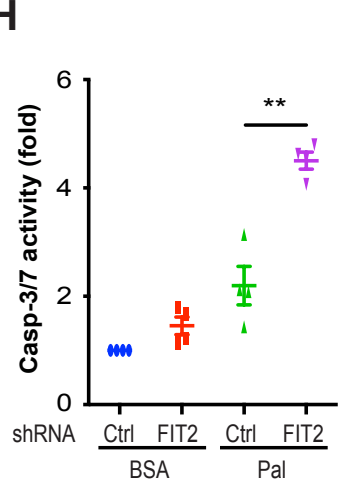$$
\text { . }
$$ 


\section{Fig4}

A

FIT2

$\beta$-actin

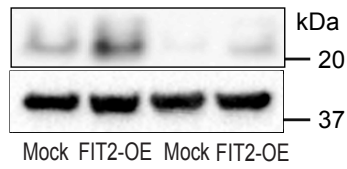

B

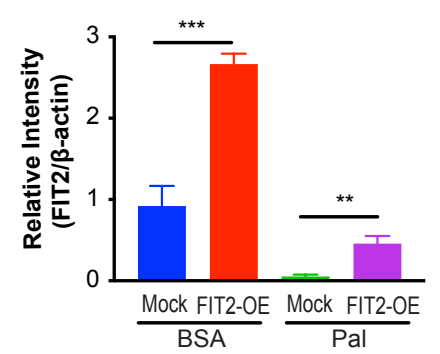

E

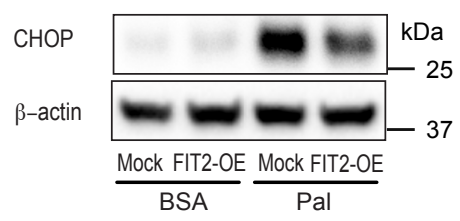

C

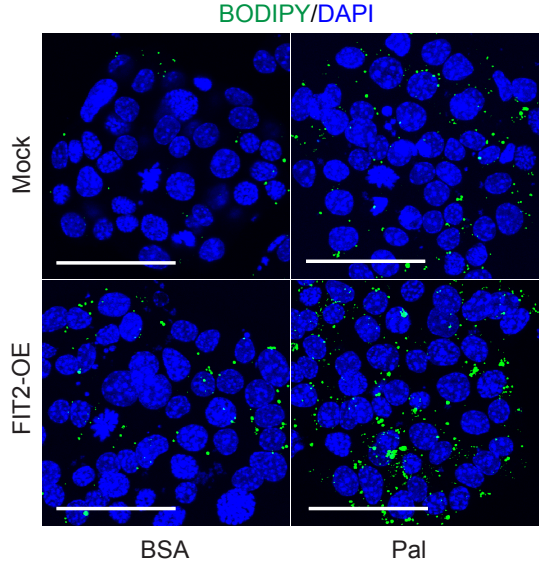

F

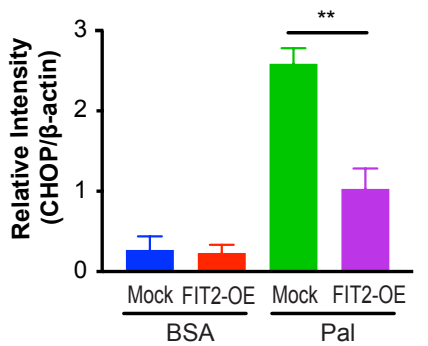

D

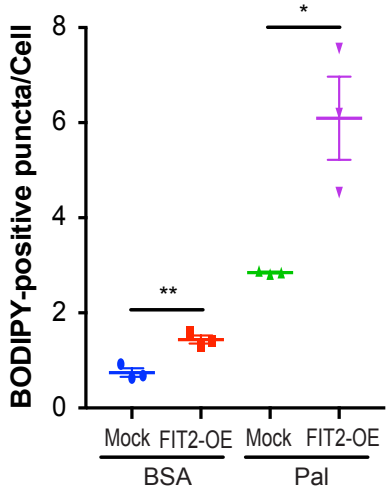

G

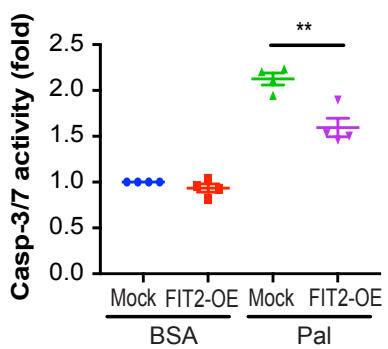




\section{Fig5}

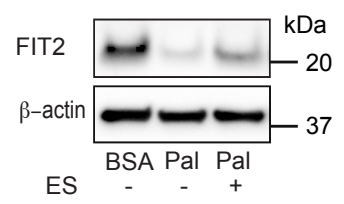

A

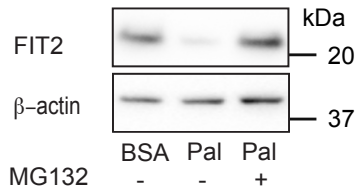

B

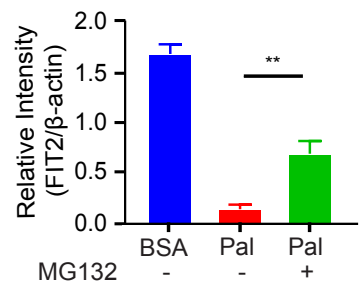

C
D

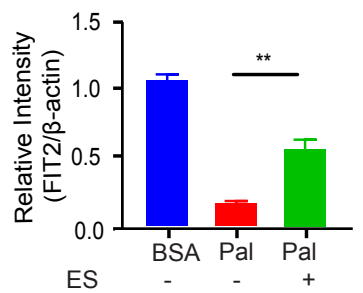

E

IB: MARCH6

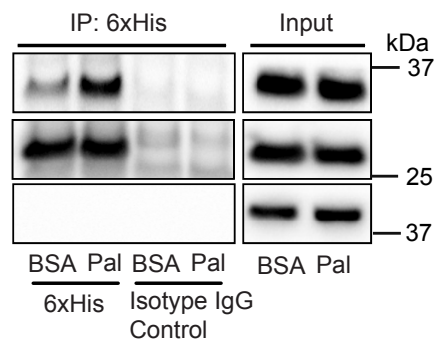

F

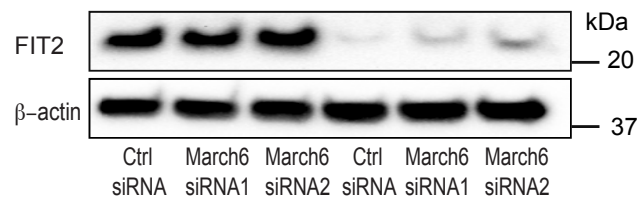

BSA
H

C7/70/

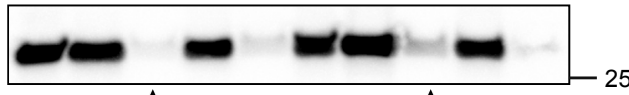

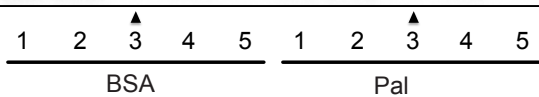

1: IF

2: $\mathrm{CUF}$

3: $\mathrm{CBF}$

4: $p U F$

5: $\mathrm{pBF}$

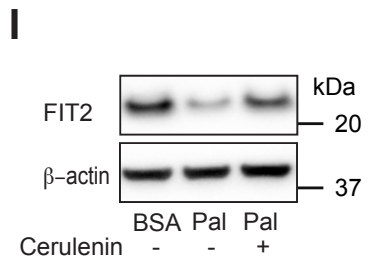

$140 / 251 \mathrm{~A}$

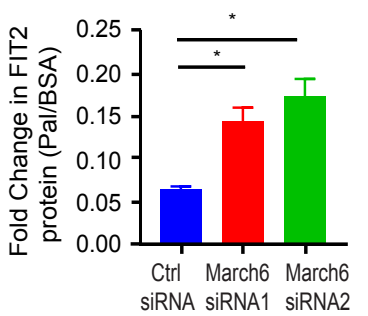

G

J

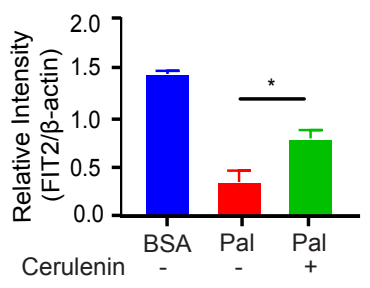

K

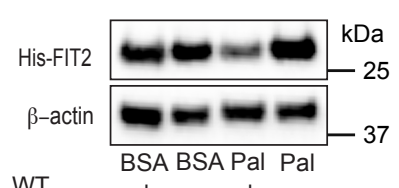

WT

C7/70/140/251A - + - +
L $\left.\quad \stackrel{\mathbb{E}}{\frac{\mathbb{t}}{\mathrm{w}}}{ }^{1.5}\right]$ **

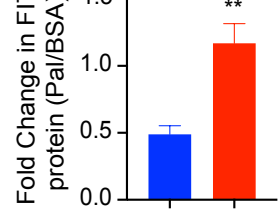

WT
C7/70/140/251A 
A

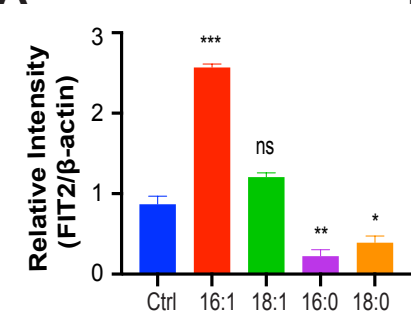

E

FIT2 / INS / DAPI
B

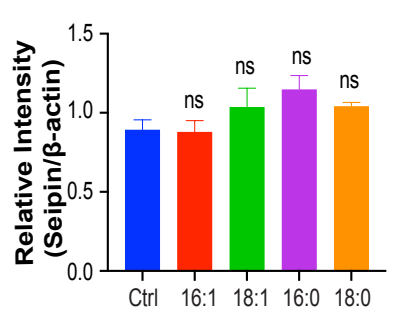

F

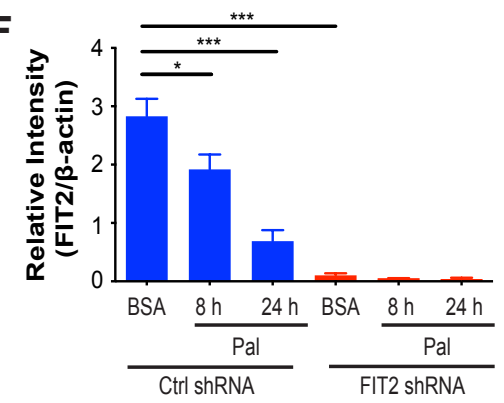

C

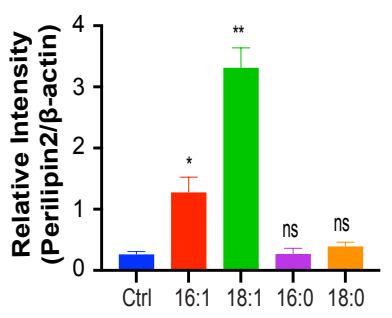

G

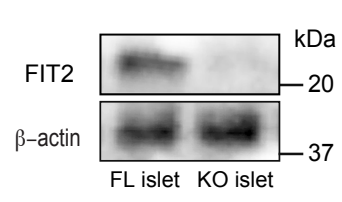

$\mathrm{FL}$ islet $\mathrm{KO}$ islet
D

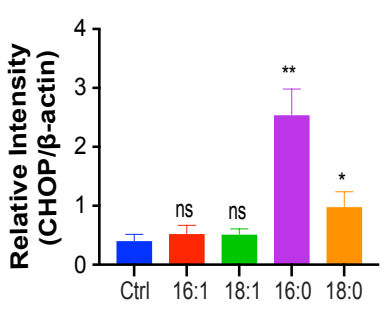

H

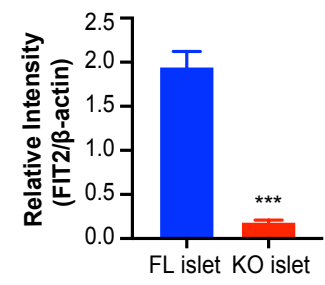

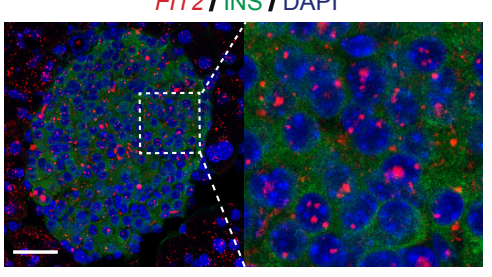


A

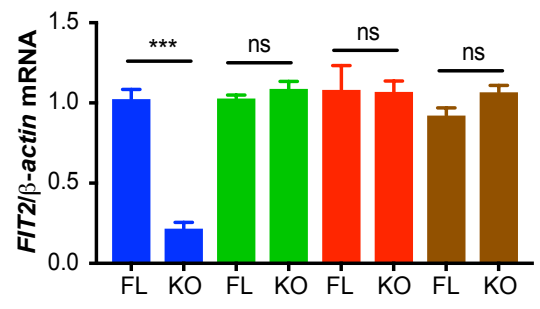

B

- Islet

eWAT

- Liver

Hypothalamus

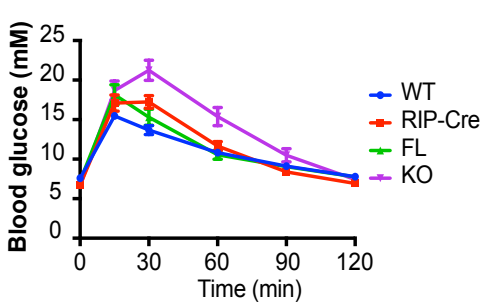

E $F$

D

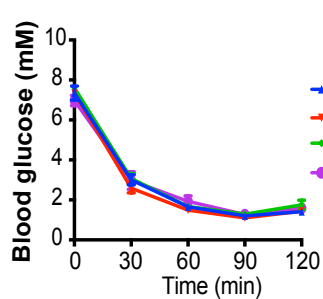

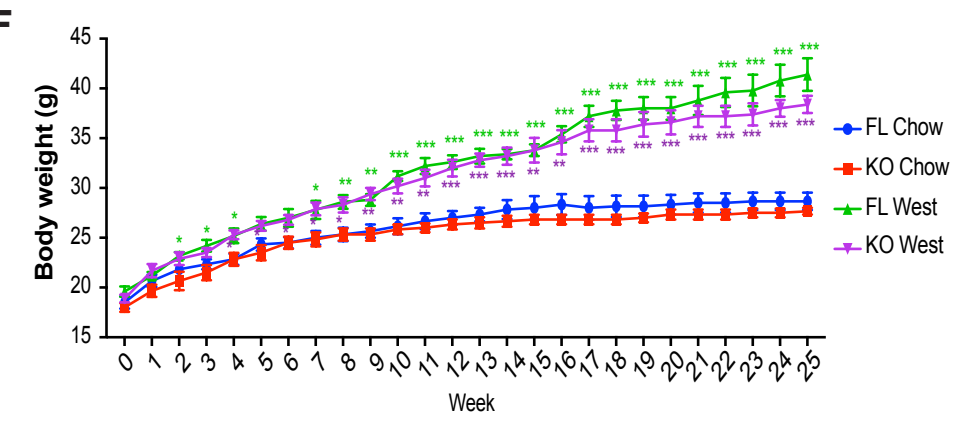

C

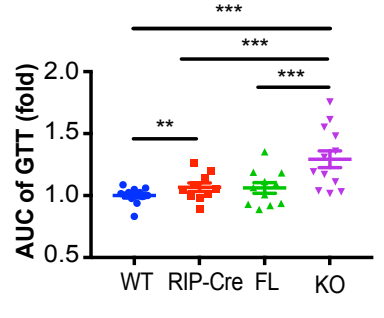


Fig S3

A

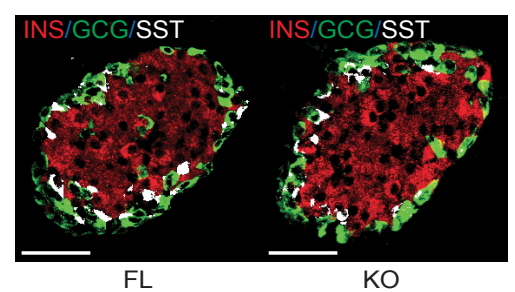

E

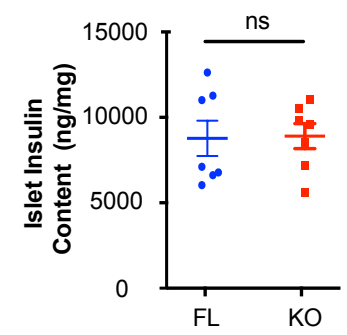

F

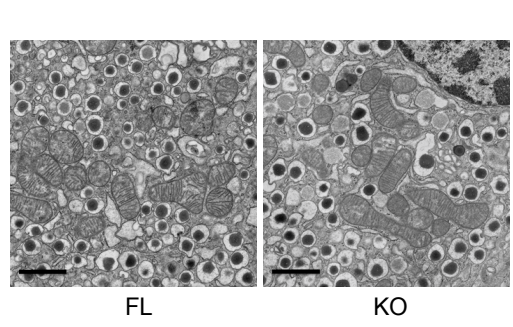

B

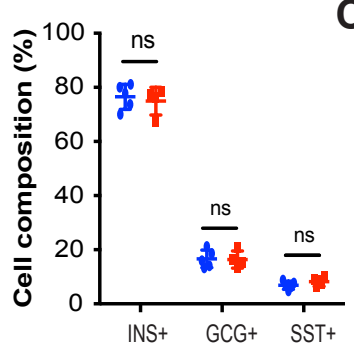

C

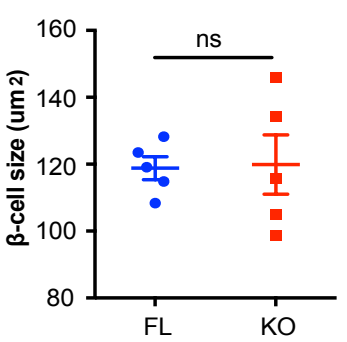

G

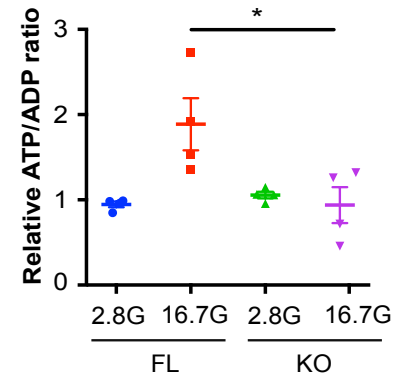

H
D
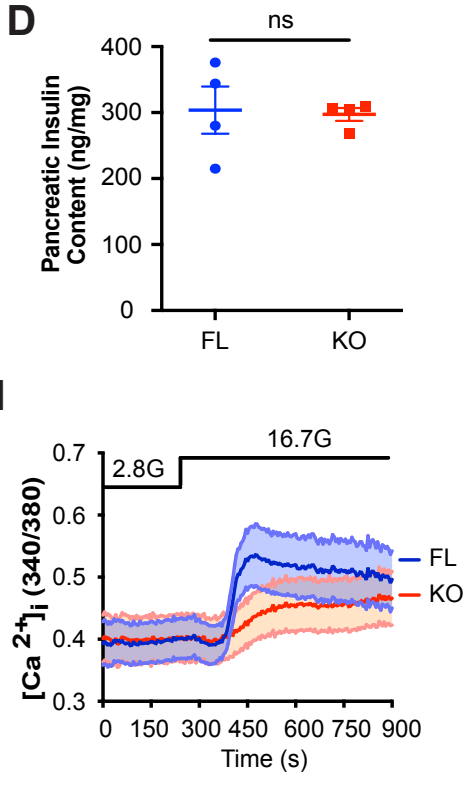

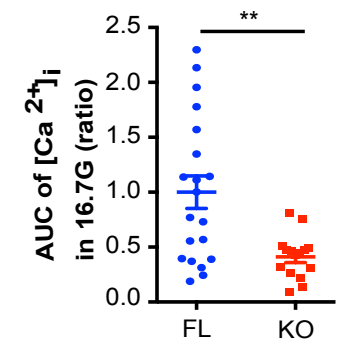


Fig $\$ 4$

A

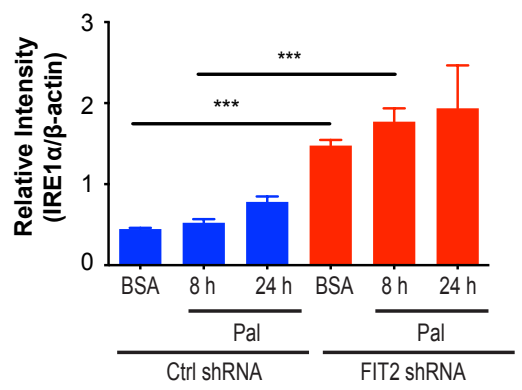

D

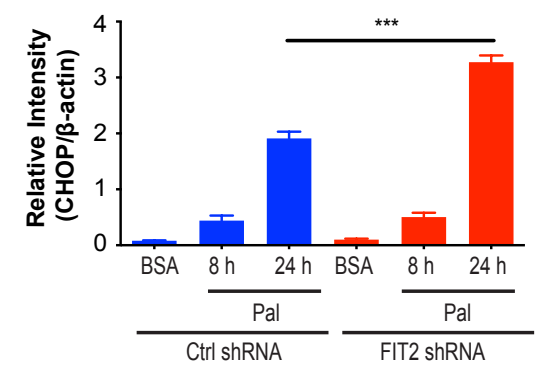

B

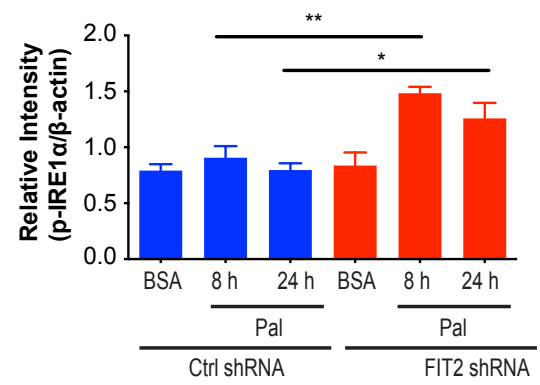

E

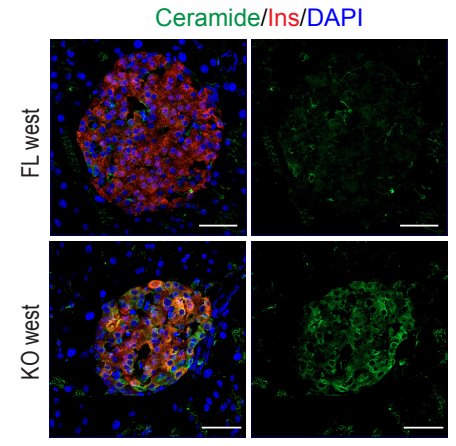

C

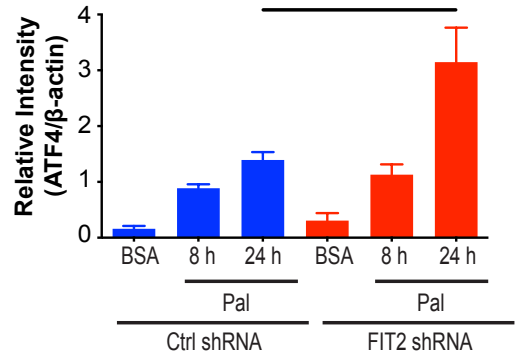

F

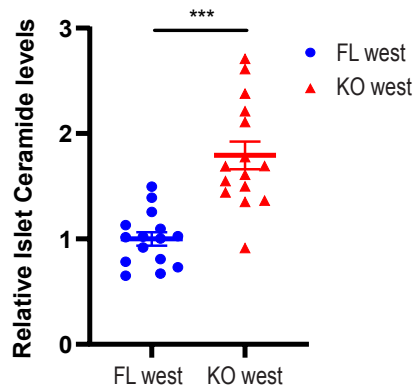


A

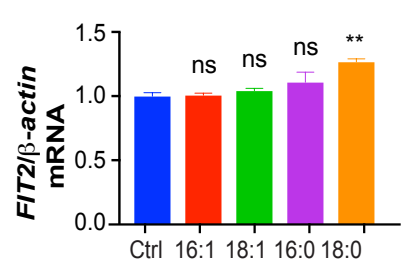

B

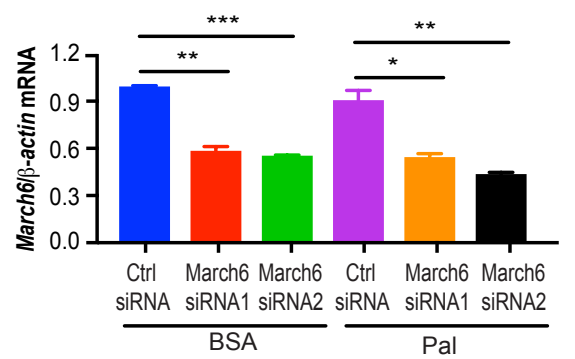

C

WT

C7A

C70A

C140A

C251A

C7/70/140/251A

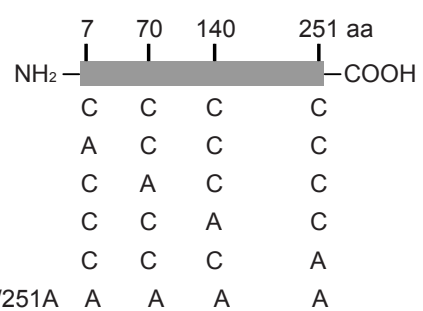

$\mathbf{F}$
D

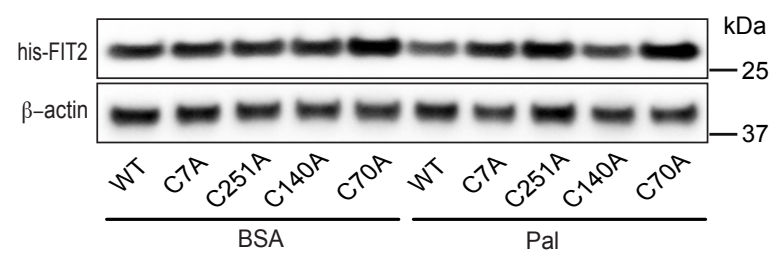

G C7/70/140/251A

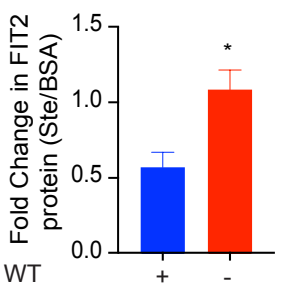

E

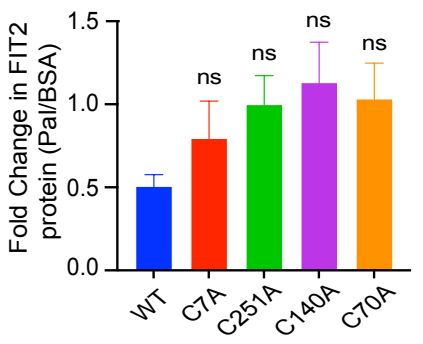

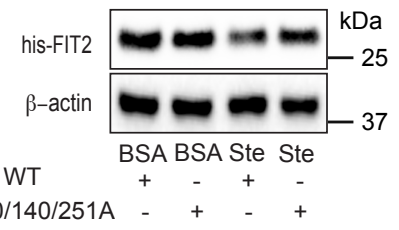
$\mathrm{C} 7 / 70 / 140 / 251 \mathrm{~A}-\quad+\quad+\quad+$ 